\title{
Diagnostic Assessment and Restoration Plan for Damaged Forest around the Seokpo Zinc Smelter, Central Eastern Korea
}

\author{
A Reum Kim ${ }^{1}\left(\mathbb{D}\right.$, Bong Soon $\operatorname{Lim}^{1}{ }^{1}$, Jaewon Seol ${ }^{1}$, Chi Hong $\operatorname{Lim}^{2}{ }^{\circledR}$, Young Han You ${ }^{3}$, Wan Sup Lee ${ }^{4}$ \\ and Chang Seok Lee ${ }^{1, *}$ (i)
}

check for

updates

Citation: Kim, R.A.; Lim, B.S.; Seol, J.; Lim, C.H.; You, Y.H.; Lee, W.S.; Lee, C.S. Diagnostic Assessment and Restoration Plan for Damaged Forest around the Seokpo Zinc Smelter, Central Eastern Korea. Forests 2021, 12, 663. https://doi.org/10.3390/ f12060663

Academic Editors: Ovidiu Badea, Alessandra De Marco, Pierre Sicard and Mihai A. Tanase

Received: 16 April 2021

Accepted: 21 May 2021

Published: 24 May 2021

Publisher's Note: MDPI stays neutral with regard to jurisdictional claims in published maps and institutional affiliations.

Copyright: (c) 2021 by the authors. Licensee MDPI, Basel, Switzerland. This article is an open access article distributed under the terms and conditions of the Creative Commons Attribution (CC BY) license (https:// creativecommons.org/licenses/by/ $4.0 /)$.
1 Division of Chemistry and Bio-Environmental Sciences, Seoul Women's University, Seoul 01797, Korea; dkfma@swu.ac.kr (A.R.K.); bs6238@swu.ac.kr (B.S.L.); seol_jaewon@swu.ac.kr (J.S.)

2 Division of Ecological Survey Research, National Institute of Ecology, Seoul 33657, Korea; sync03@nie.re.kr

3 Department of Biology, Kongju National University, Kongju 32588, Korea; youeco21@kongju.ac.kr

Samseong Landscape Co., Ltd., Andong 36665, Korea; kjc3700@hanmail.net

* Correspondence: leecs@swu.ac.kr; Tel.: +82-2-970-5666

\begin{abstract}
Research Highlights: This study was carried out to diagnose the forest ecosystem damaged by air pollution and to then develop a restoration plan to be used in the future. The restoration plan was prepared by combining the diagnostic assessment for the damaged forest ecosystem and the reference information obtained from the conservation reserve with an intact forest ecosystem. The restoration plan includes the method for the amelioration of the acidified soil and the plant species to be introduced for restoration of the damaged vegetation depending on the degree of damage. Background and Objectives: The forest ecosystem around the Seokpo smelter was so severely damaged that denuded lands without any vegetation appear, and landslides continue. Therefore, restoration actions are urgently required to prevent more land degradation. This study aims to prepare the restoration plan. Materials and Methods: The diagnostic evaluation was carried out through satellite image analysis and field surveys for vegetation damage and soil acidification. The reference information was obtained from the intact natural forest ecosystem. Results: Vegetation damage was severe near the pollution source and showed a reducing trend as it moved away. The more severe the vegetation damage, the more acidic the soil was, and thereby the exchangeable cation content and vegetation damage were significantly correlated. The restoration plan was prepared by proposing a soil amelioration method and the plants to be introduced. The soil amelioration method focuses on ameliorating acidified soil and supplementing insufficient nutrients. The plants to be introduced for restoring the damaged forest ecosystem were prepared by compiling the reference information, the plants tolerant to the polluted environment, and the early successional species. The restoration plan proposed the Pinus densiflora, Quercus mongolica, and Cornus controversa-Juglans mandshurica communities as the reference conditions for the ridge, slope, and valley, respectively, by reflecting the topographic condition. Conclusions: The result of a diagnostic assessment showed that ecological restoration is required urgently as vegetation damage and soil acidification are very severe. The restoration plan was prepared by compiling the results of these diagnostic assessments and reference information collected from intact natural forests. The restoration plan was prepared in the two directions of soil amelioration and vegetation restoration.
\end{abstract}

Keywords: air pollution; diagnostic assessment; forest ecosystem; reference information; restoration plan

\section{Introduction}

Most developed countries have decreased anthropogenic air pollution emissions by implementing abatement polices [1,2]. Korea has also practiced such a policy, and thus environmental conditions around the industrial complexes of large scale have improved greatly [3,4]. 
However, factories of a small scale that are far away from the public's attention, such as the Seokpo smelter where this study was carried out, still emit air pollutants and thereby cause vegetation damage and acidify soil. The forest ecosystem around the Seokpo zinc smelter was severely destroyed and therefore landslides sometimes occur. Industrial activities have resulted in the enormous emissions of air pollutants for about 40 years since the 1970s when the smelter was constructed in Seokpo in central eastern Korea. The pollutants have continued to affect the surrounding forests and other ecosystems. Forest vegetation has become sparse and poor as trees have withered, undergrowth has disappeared, and bare ground has appeared throughout the wide area.

Pollutants discharged beyond the limits of the buffering capacity of an ecosystem prevent it from maintaining its normal structure and function. Excessive land and energy use and the ecological imbalance that it brings appear to be major factors that threaten environmental stability on local as well as global levels [4-8]. The vegetation decline and subsequent soil erosion and landslides observed in the vicinity of the Seokpo zinc smelter correspond to such an example. In fact, global environmental problems such as climate change are also due to this functional imbalance between the pollution source and the sink [9-11].

If the population grows and the land and energy use continue to intensify, such ecological imbalance is likely to increase even more in the future $[7,12,13]$. Indeed, industrialized and urbanized areas have been expanding steadily, and the real size of degraded vegetation, such as grassland and shrubland, has increased proportionally to such land transformation in industrial areas of Korea $[4,7,8,14,15]$. Moreover, vegetation decline induces the structural simplification and functional weakening of plant communities, consequently leading to negative effects on ecosystem service, which provides invaluable benefits to us $[12,13]$. In this respect, the restoration of degraded ecosystems is urgently required to prevent the spread of such additive pollution damage $[4,7,13,16]$.

Ecological restoration is aimed at recovering the sound natural conditions before destruction. Ecological restoration is an ecological technology that heals the damaged nature by imitating the system and function of the integrated nature, thus providing habitats for various creatures and seeking to secure the future environment of humankind [17-20]. Ecological restoration has been considered as improving ecological productivity in degraded lands, conserving biological diversity, and mitigating lost or damaged ecosystems [19-28]. Human aids are often required to restore the damaged ecosystems and prevent further damage $[16,19,20,29]$, and provisions of extra propagules and site amendment may initiate recovery processes [30].

In order to heal the damaged nature, we must first check what problems the target has, such as how much it is degraded or what is the cause of the damage. In other words, a diagnostic assessment of the restoration target should be made $[19,20]$.

All restoration projects are with targets to reduce the negative ecological impacts of the past and to restore the natural potential of the restoration target as much as possible. Ecological restoration means copying nature by studying a system of the integrate nature. There are several planning steps, based on the results of diagnostic assessments, to find the deficits and the targets for planning to improve the degraded ecosystem. First of all, we have to prepare such measures by obtaining diverse ecological information on an area to be restored because specific restoration efforts have to be applied in the field [31-33].

The restoration of an ecosystem damaged by environmental pollution can be achieved either through improvement of the environment polluted or by establishing plants tolerant to the pollutants $[7,8,13,16,29,34-36]$. Species tolerant to environmental pollution can persist through growth and reproduction or even expand their distribution range in the polluted environment $[5-8,37,38]$.

The Seokpo smelter is uniquely located on a small mountain village and is thus far away from the public's attention. Therefore, little is known about the situation and, moreover, no academic research has been carried out. However, due to the effects of air pollutants emitted over a long period of time and the soil pollution resulting from them, 
the forest damage began to become visible, and it has led to landslides and damage to surrounding rivers in good condition, causing worry in recent years. There is, therefore, a growing demand for restoration. The major pollution source of the Seokpo smelters, which refines primarily processed ore rather than raw ore, is sulfur dioxide generated from the combustion of fossil fuels used as an energy source. The damage state was similar to that of Ulsan and Yeocheon industrial complexes, major industrial complexes in Korea $[4,7,8,12,36]$.

Restoration is an ecological technology that ameliorates degraded nature by imitating integrated and healthy nature. Restoration is achieved through a series of procedures, such as a survey of the existing conditions, a statement of the goals and objectives, the designation and description of a reference, the preparation of a master plan, the establishment of a restoration plan, restoration practices, monitoring, adaptive management, and evaluation [39-42]. Such ecological restoration is common as a means to solve such problems in developed countries, which correctly recognize that the environmental problems at a global level, such as climate change, are due to the functional imbalance between the artificial environment as an environmental stress source and the natural environment as its sink. However, in most developing countries, including Korea, most restoration projects have neglected such procedures and thus have not met the restoration goals, in spite of great expense and labor [43-50]. A series of procedures are required to achieve successful ecological restoration. However, these procedures usually tend to be ignored in most restoration projects implemented in Korea. Diagnostic evaluation is generally omitted. Even if a diagnostic evaluation is made, there are very few cases in which the level and method of restorative treatment are determined based on the results, and most restoration projects progress only by active methods without any relation to the degree of damage $[46,49]$. Therefore, cost and energy are wasted, and the effect is very little $[46,47,50]$. In most restoration projects, the reference information is not used, and restoration is performed based on the subjective decisions of the project manager. Thus, restoration projects are conducted without any model or goals. Consequently, exotic species, which should be excluded thoroughly in a restoration project, are introduced frequently, and the spatial distribution range for plant species is barely considered [46,47,50]. Therefore, most restoration projects remain at the level of past afforestation or classical landscaping.

This study was attempted to implement ecological restoration of the advanced level, which is beyond this low level of restoration. This study conducted a diagnostic evaluation for the damaged forest from air and soil pollution, collected reference information from intact forest without any damage, and prepared a restoration plan by combining such information. In order to ecologically restore the area, the following situations need to be considered: first, since pollutants continue to be emitted, tolerant plants that can withstand such pollution should be selected and introduced. Second, soils contaminated by the effects of pollutants discharged for a long time should be improved. Third, many species have already disappeared due to environmental pollution, and thus we need to introduce species that have disappeared based on the ecological information obtained from the reference ecosystem. Finally, since the environment has been severely damaged to the point where landslides occur, measures should also be taken to prevent landslides when establishing the planting bed. This study aims to clarify the extent and the type of damaged forest and, furthermore, to recommend a restoration plan suitable for the ecological condition of the target site as well as the damage degree based on the principle of restoration ecology. In order to arrive at these goals, we assessed vegetation damage based on satellite image interpretation and field checks. Vegetation damage was also assessed based on species composition and species diversity. Furthermore, we also diagnosed the damaged state of soil based on its physic-chemical properties. We recommended the restoration plan by synthesizing the results of the diagnostic assessment and the reference information, including pollution tolerant species and early successional species considering the environmental condition of this area. 


\section{Materials and Methods}

\subsection{Study Site}

This study was carried out in the forest ecosystem around the Seokpo smelter, located on the central eastern Korea (Figure 1). The Seokpo smelter has been in operation since 1970. The smelter produces zinc, cadmium sulfate, copper sulfate, and manganese sulfate and has emitted many air pollutants around it [51]. This area is surrounded by mountainous areas with steep slopes and has topographical features that make it difficult for air pollutants to spread (Figure 2) $[4,6,16]$. In addition, the temperature inversion, which occurs as the cold air on the mountain descends along the surrounding mountain slopes and is trapped at the bottom of the basin after sunset, makes it more difficult to spread air pollutants, causing an increase in pollution damage in this narrow valley. During this temperature inversion time, dense smoke often settles in low-lying areas and becomes trapped due to temperature inversions-when a layer within the lower atmosphere acts as a lid and prevents vertical mixing of the air. Steep canyon walls act as a horizontal barrier, concentrating the smoke within the deepest parts of the canyon and increasing the strength of the inversion $[52,53]$.

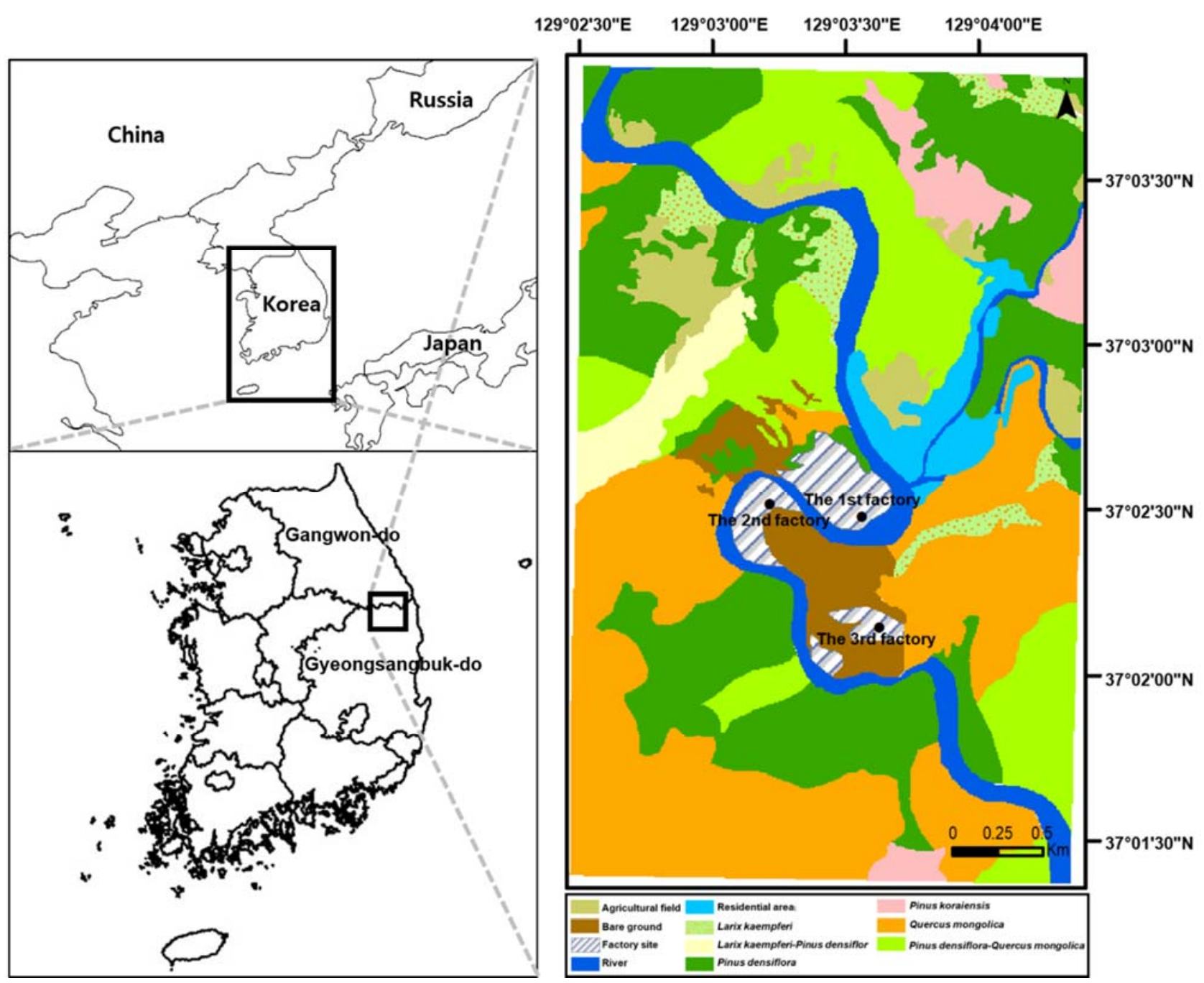

Figure 1. A map showing the study area, the Seokpo zinc smelter, which is located in central eastern Korea. Seokpo zinc smelter is composed of three factories. A colored map shows vegetation and land use types established around the smelter. Dots and the parts expressed with oblique lines around them indicate factories and factory sites.

As is shown in a vegetation map in Figure 1, the vegetation of this area is dominated by the Quercus mongolica community. However, the Pinus densiflora community is established 
on the slopes of mountainous areas with steep slopes or mountain ridges and peaks with shallow soil depth due to edaphic characteristics. There is also a mixed forest in which two species forming a community together. On the other hand, there are plantations where Larix kaempferi and P. koraiensis are introduced artificially in some areas, and there are places where mixed forests are formed where natural vegetation is mixed with planted species. Meanwhile, agricultural and residential areas are established in the lowlands.
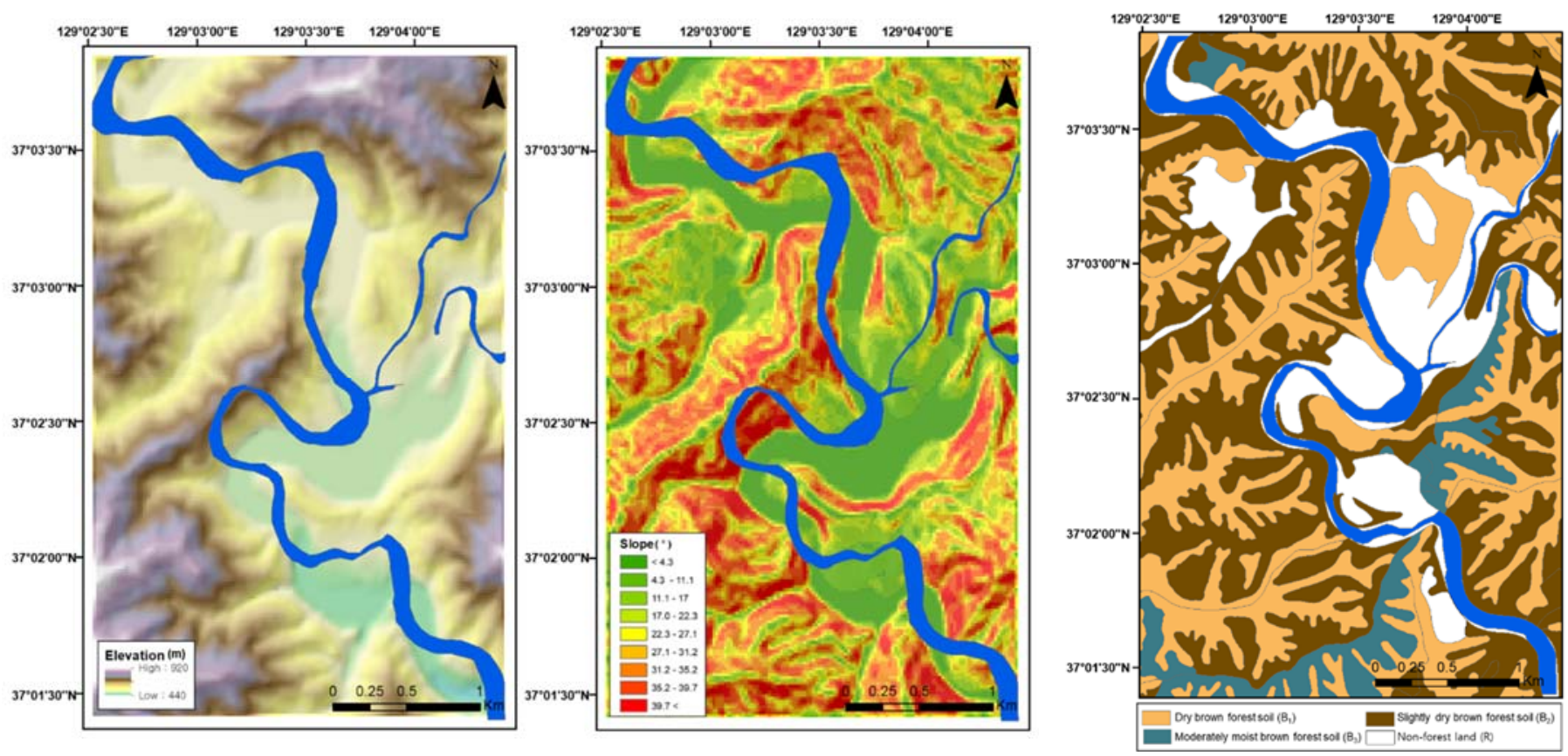

Figure 2. Maps showing the spatial distribution of elevation (m), slope (degree), and soil type in the study area.

The climate of Bonghwa is continental, with warm and moist summers and cold and dry winters. The mean annual temperature is $9.9^{\circ} \mathrm{C}$ and the high and low mean temperatures are recorded as $28.6{ }^{\circ} \mathrm{C}$ and $-10.3^{\circ} \mathrm{C}$ in August and January, respectively. The mean annual precipitation is $1217.9 \mathrm{~mm}$; about $60 \%$ falls in the rainy season from June to August and, including the typhoon season of September, about $70 \%$ is concentrated in both periods [54].

The elevation of the study area ranges from 400 to $900 \mathrm{~m}$ above sea level. The slope degree is as steep as more than $20^{\circ}$ in most of the mountainous land except the valley. The parent rock of the study area consists mostly of granite, and in the flat land beside rivers and streams consists of alluvium. Soil in this area is composed of dry (B1), slightly dry (B2), and moderately moist brown forest soil (B3), which were developed on granite bedrock [55] (Figure 1).

The reference forest, used for comparison, was designated as the Korean red pine (Pinus densiflora Siebold \& Zucc.) and oak (Quercus mongolica Fisch. Ex Ledeb., and $Q$. variabilis Blum communities), which are the representative late successional vegetation types in Korea, and Cornus controversa Hemsl. ex Prain, which represents the valley forest [56]. The reference forests were selected in the Uljin genetic resource reserve, which are about $15 \mathrm{~km}$ from this study area and therefore retain a healthy vegetation. The reference forests were selected as the forests that are from 50 to 100 years old, which is not an old growth forest but a stable forest. The number of plots chosen for the survey for the reference forests was 10,10, and 10 for the P. densiflora, Q. mongolica, and Cornus controversa communities, respectively. 


\subsection{Methods}

A vegetation map was made based on image interpretation and field checks. Aerial photo images (1:5000 scale) were used to identify the vegetation types and boundaries, which appear as a homogeneous patch. These vegetation types were confirmed by field checks. Vegetation types were overlapped onto topographical maps at a 1:5000 scale. Patches smaller than $1 \mathrm{~mm}$ on the map were excluded from this study because of the uncertainty of their sizes and shapes [57]. The final map was constructed with ArcGIS program (ver. 10.0, ESRI, Redlands, CA, USA) [58].

To determine the vitality of vegetation in the study area, Landsat images taken on 2 October 2018 were downloaded to analyze the normalized differential vegetation index (NDVI). Vegetation damage based on vitality was assessed through supervising analysis on the satellite image [59]. This study applied a supervised classification-maximum likelihood algorithm to classify the vegetation damage state around the Seokpo zinc smelter using Landsat images in the ArcGis10.1 program. The maximum likelihood algorithm is the most common method in remote sensing image data analysis [60], which is mainly controlled by selecting the pixels that are representative of the desired classes [61]. Using the signature file creation tool, vegetation damage was classified into five classes of very severe, severe, moderate, light, and none. The damage degrees classified were verified through field checks as follows.

Visible damage was investigated by recording the degree of necrosis that appeared on the leaf surface of plants appearing in the process of the vegetation survey. The damage degree was classified into five groups based on the percentage of injury shown on the leaf surface: very severe (V, more than $75 \%$ of total leaf area damaged), severe (IV $50-75 \%$ damaged), moderate (III, $25-50 \%$ damaged), light (II, less than $25 \%$ damaged), and none (I, $0 \%$ [ [7].

The vegetation structure damage was assessed by the deformation of vegetation stratification based on [62]. More than $50 \%$ of the land, which is covered with barren ground was assessed as 'very severe'. Grassland or barren ground without any woody plants was assessed as 'severe'. Vegetation that had lost some stratification was assessed as 'moderate'. Vegetation with visible damage only to integrate structure, with all strata composed of canopy, understory, shrub, and herb layers shown without any loss of stratification was assessed as 'light'. A map expressing vegetation damage was prepared by applying the GIS program (ver. 10.0, ESRI, Redlands, CA, USA).

The vegetation survey was carried out from May to September in 2018 and 2019. The vegetation survey was carried out by recording the Braun-Blanquet's cover class of plant species appearing in quadrats of $2 \mathrm{~m} \times 2 \mathrm{~m}, 5 \mathrm{~m} \times 5 \mathrm{~m}$, and $20 \mathrm{~m} \times 20 \mathrm{~m}$ size in grassland, shrubland, and forest, respectively, installed randomly [63]. The vegetation survey was carried out in 99 plots $(28,28,1,5,5,19$, and 13 plots for Pinus densiflora community, Quercus mongolica community, $Q$. variabilis community, valley forest, shrubland, grassland, and cut slope, respectively) from May to September in 2018 and 2019.

Soil samples were collected with a sampling spade in June-August 2019 from the top $10 \mathrm{~cm}$ after removing the litter at five random points in each plot, after which they were pooled, air dried at room temperature, and sieved through $2 \mathrm{~mm}$ mesh. A total of 18, 18, 1, $3,3,12$, and 9 soil samples were collected from the Pinus densiflora community, the Quercus mongolica community, the $Q$. variabilis community, valley forest, shrubland, grassland, and cut slope, respectively. Soil properties were diagnosed for $\mathrm{pH}$ and $\mathrm{Ca}^{2+}, \mathrm{Mg}^{2+}$, and $\mathrm{Al}^{3+}$ content. Soil $\mathrm{pH}$ was measured with a bench top probe after mixing the soil with distilled water (1:5 ratio, $\mathrm{w} / \mathrm{v}$ ) and filtering the extract (Whatman No. 44 paper). Organic matter $(\mathrm{OM})$ concentration was estimated by loss of dry mass on ignition at $400^{\circ} \mathrm{C}$. Total nitrogen was measured with the micro-Kjeldahl method [64]. Available P was extracted in 1-N ammonium fluoride $(\mathrm{pH}=7.0)$ and exchangeable $\mathrm{Ca}^{2+}, \mathrm{Mg}^{2+}$, and $\mathrm{Al}^{3+}$ contents were extracted with $1 \mathrm{~N}$ ammonium acetate $(\mathrm{pH}=7.0$ for $\mathrm{Ca}$ and $\mathrm{Mg}$ and $\mathrm{pH}=4.0$ for $\mathrm{Al})$ and measured by ICP (inductively coupled plasma atomic emission spectrometry; Shimadzu ICPQ-1000) [65]. The results of the analysis on the physic-chemical properties of soil were 
reinforced by the simple kriging model. Maps expressing the physic-chemical properties of the soil were prepared by applying the GIS program (Version 10.1). The soil properties $(\mathrm{pH}$, $\mathrm{OM}, \mathrm{N}, \mathrm{P}, \mathrm{Ca}, \mathrm{Mg}$ and $\mathrm{Al}$ ) of sites showing different degrees of damage to vegetation were compared with one-way analysis of variance (ANOVA) and Tukey's honestly significant difference (HSD) test at $\alpha=0.05$ [66].

The restoration plan was prepared by recommending a soil amelioration method and the plant species to be introduced depending on the degree of damage to the vegetation and soil. Dolomite and organic fertilizer were recommended for soil amelioration. The dolomite requirement was calculated by applying the following equation: dolomite requirement $(\mathrm{t} / \mathrm{ha})=($ target $\mathrm{pH}$-current $\mathrm{pH}) \times$ soil texture factor. We decided to set the target $\mathrm{pH}$ as 5.5, based on the normal $\mathrm{pH}$ of the natural forest soil, and soil texture factor as 3 , reflecting the soil texture of this area [67]. Dolomite raises the soil $\mathrm{pH}$ and increases available $\mathrm{Ca}^{2+}$ and $\mathrm{Mg}^{2+}$ due to the following chemical reactions in the soil solution [68]:

$$
\begin{aligned}
& \text { Initial chemical reaction: } \mathrm{Ca} \bullet \mathrm{Mg}\left(\mathrm{CO}^{3}\right)_{2}+2 \mathrm{H}^{+} \rightarrow 2 \mathrm{HCO}_{3}{ }^{-}+\mathrm{Ca}^{2+}+\mathrm{Mg}^{2+}, \\
& \text { Second reaction: } 2 \mathrm{HCO}_{3}{ }^{-}+2 \mathrm{H}^{+} \rightarrow 2 \mathrm{CO}^{2}+2 \mathrm{H}_{2} \mathrm{O}, \\
& \text { Net reaction: } \mathrm{Ca} \bullet \mathrm{Mg}\left(\mathrm{CO}^{3}\right)_{2}+4 \mathrm{H}^{+} \rightarrow \mathrm{Ca}^{2+}+\mathrm{Mg}^{2+}+2 \mathrm{CO}^{2}+2 \mathrm{H}_{2} \mathrm{O},
\end{aligned}
$$

The amount of organic fertilizer applied was determined to be half the level of dolomite, referring to previous study results [8]. The chemical characteristics of the organic fertilizer are given in Appendix A, Table A1.

The introduction of vegetation for restoration took the form reinforcing the lost part in the vegetation stratification. Therefore, we planned to introduce the disappeared species compared to the species composition of the natural reference site. Furthermore, we added tolerant and early successional species in our restoration plan, considering the environmental condition of this area, where air and soil pollution continues and vegetation is so severely damaged that bare ground can appear and severe soil erosion occurs. The plant species to be introduced were selected by applying indicator species analysis. Indicator species analysis was carried out using the function 'vegan', 'indicspecies' of the R statistical package (version 4.0.2). In addition, we reinforced the plant species to be introduced by referring to national vegetation information [69] and existing research data conducted on the reference site of this study [70], considering that this study was conducted in a limited place.

\section{Results}

\subsection{Vegetation Damage}

The spatial distribution of NDVI showed that its value was lower near the factory and tended to increase as it moved away from it (Figure 3). The value was also related to the topographic condition; thus, it was low in the ridge and high in the valley (Figure 3). 


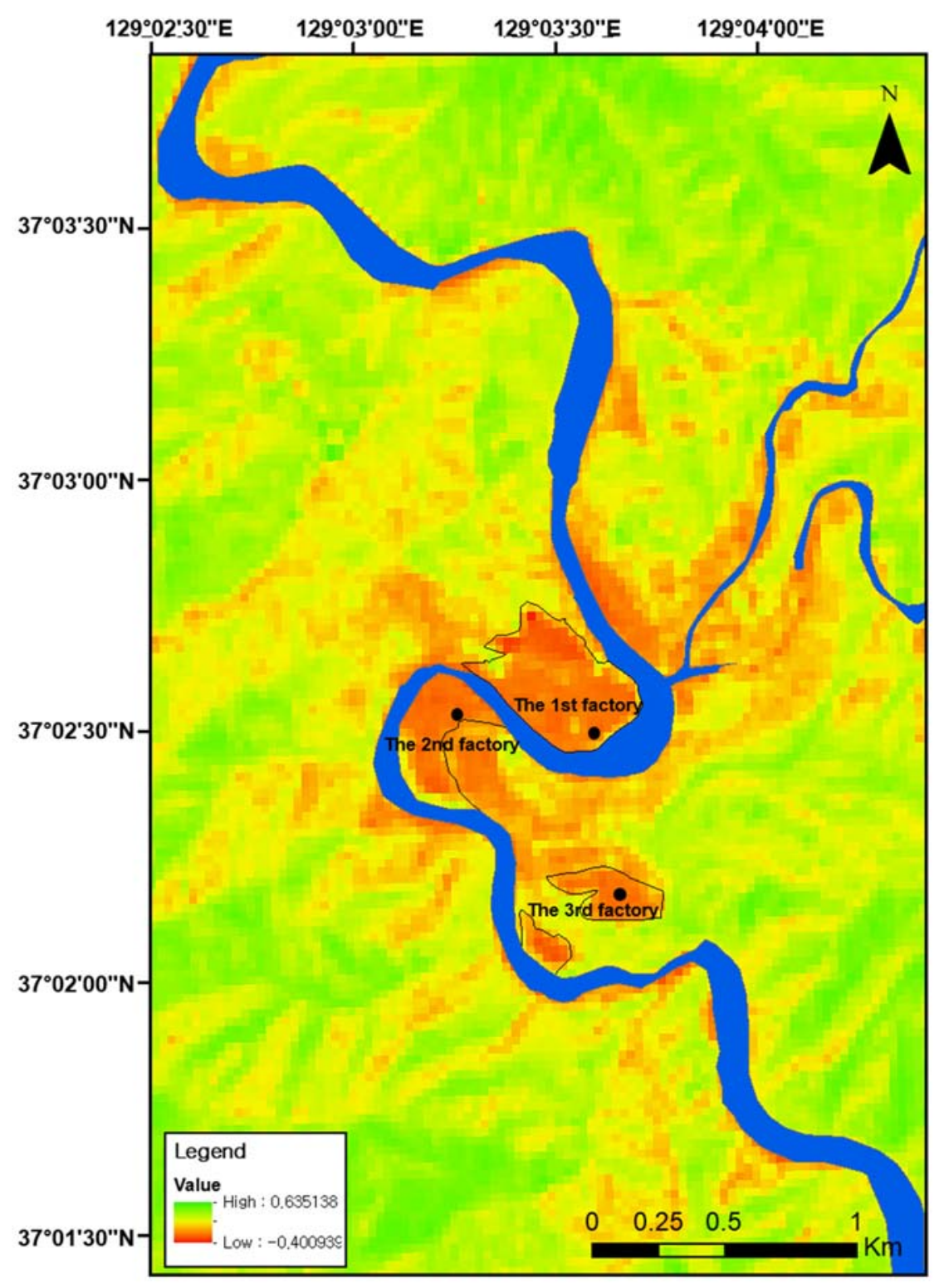

Figure 3. Spatial distribution of NDVI in the study area.

Vegetation damage identified from the satellite image interpretation depended on the distance from the smelter and topography. The damage appeared was severer in sites closer to the smelter and decreased farther away (Figure 4). The degree of damage was also dominated by topographic conditions, and therefore damage was restricted within the first ridge from the pollution source, little damage thus appearing on the opposite slope or beyond the first ridge from the smelter (Figure 4). 


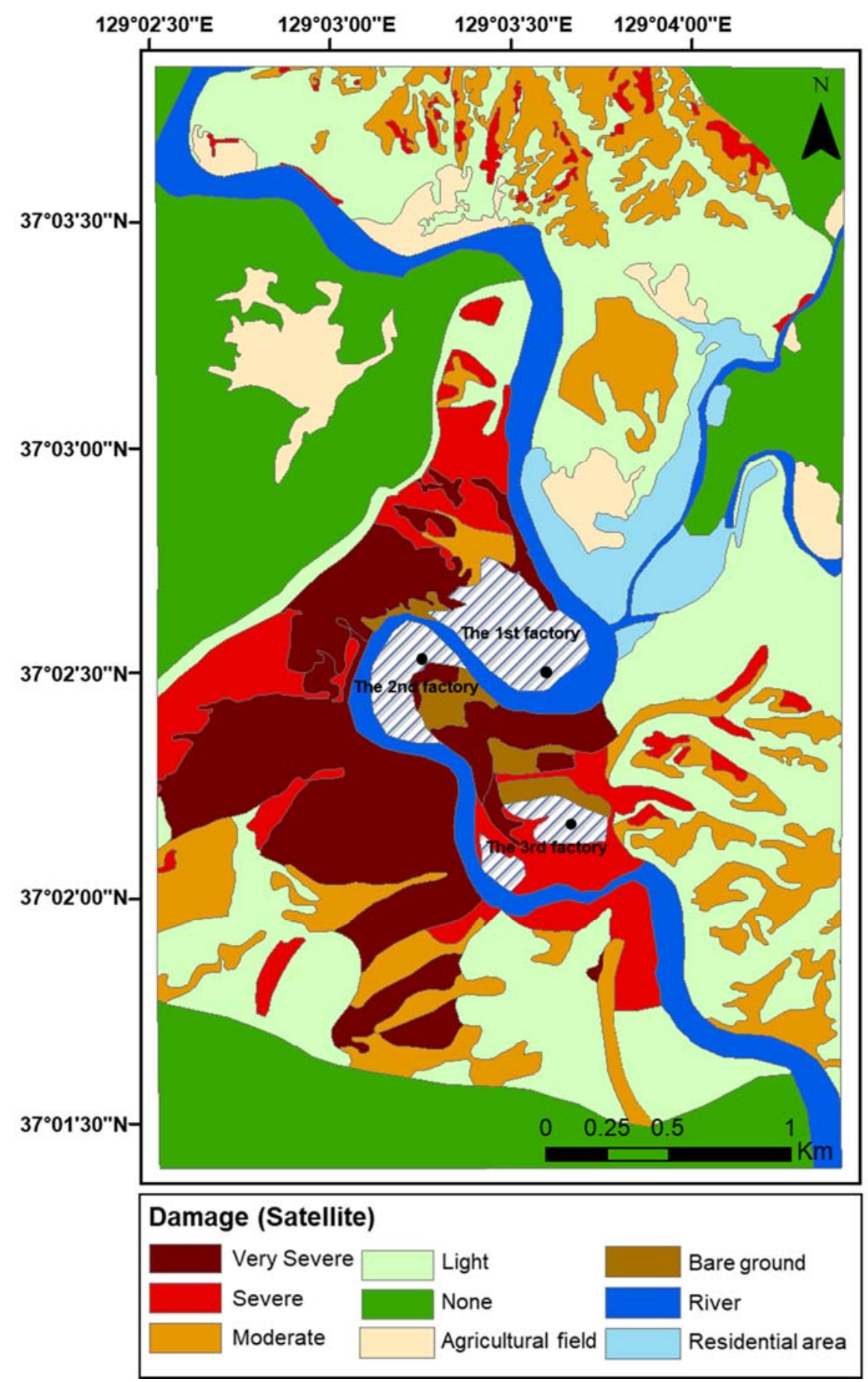

Figure 4. Spatial distribution of vegetation damage based on satellite image interpretation in the study area.

Damage based on vegetation stratification showed a trend similar to the abovementioned results. Vegetation in the site where the damage was light showed the integrate structure with all strata composed of canopy, understory, shrub, and herb layers. However, vegetation structure became simplified with the increase of the damage, and thus grassland or barren ground appeared in sites where the damage was the severest (Figure 5). 


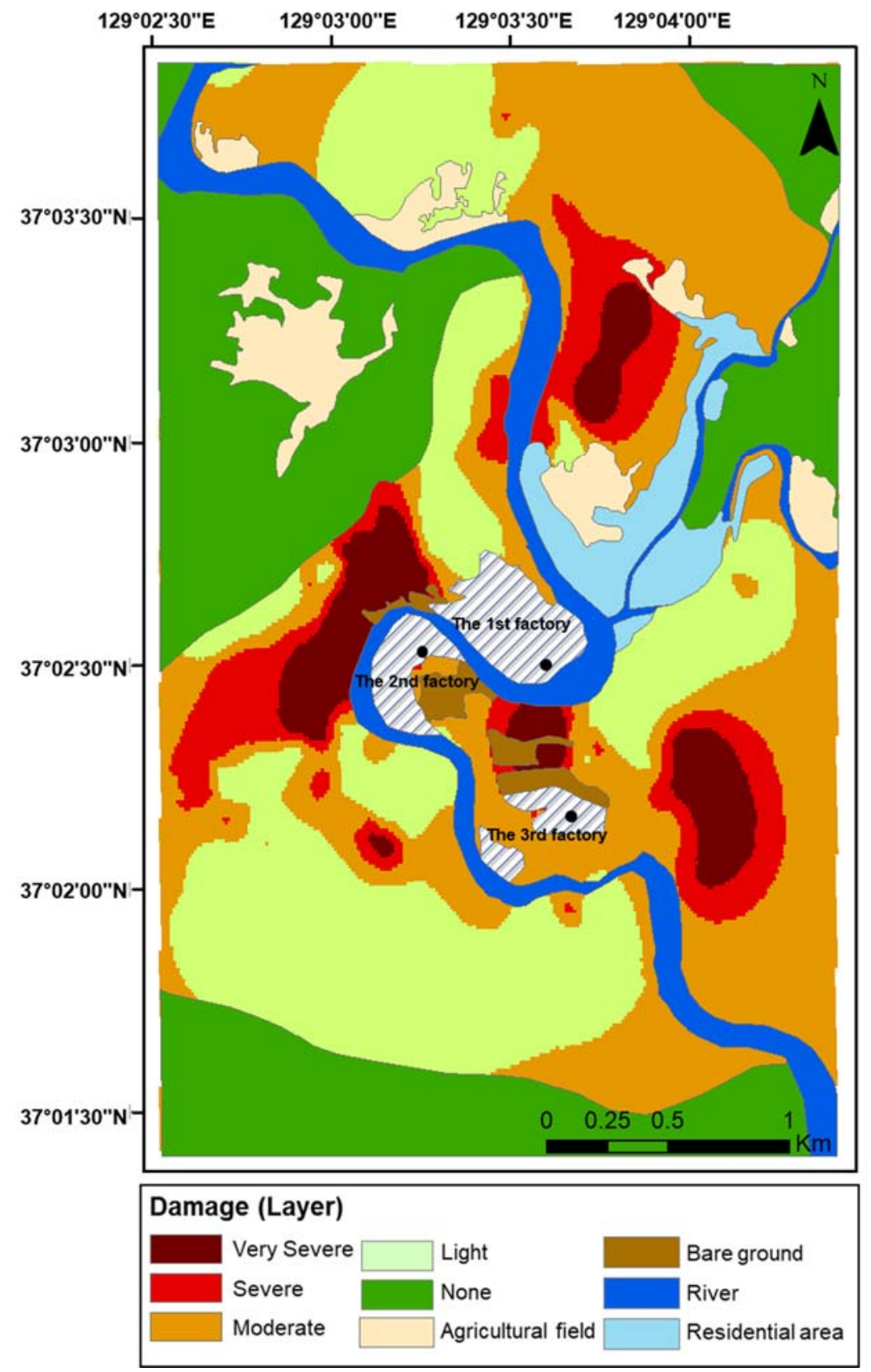

Figure 5. Spatial distribution of vegetation damage based on vegetation stratification in the study area.

In a map where vegetation damage by damage class is shown (Figure 4), very severely damaged vegetation appeared in areas located in the northwestern direction of the first factory, the western and southern directions of the second and third factory, and surrounded by the first, second, and third factories. Severely damaged vegetation appeared in the areas farther than the very severely damaged vegetation from the three factories in all four directions of east, west, south, and north. Moderately damaged vegetation appeared in the areas located in the eastern and western directions, with the third factory at the center. Lightly damaged vegetation appeared in the areas far from them within the first ridge from the factories.

\subsection{Soil Degradation}

Spatial distribution of the physic-chemical properties of the soil reflected a trend of vegetation damage. Soil $\mathrm{pH}$ was usually low compared with the unpolluted area but was lower in sites close to pollution sources and became higher farther away (Figure 6).The 
$\mathrm{Ca}^{2+}$ and $\mathrm{Mg}^{2+}$ content showed trends similar to that of the $\mathrm{pH}$, whereas $\mathrm{Al}^{3+}$ content represented a reverse trend (Figure 6).
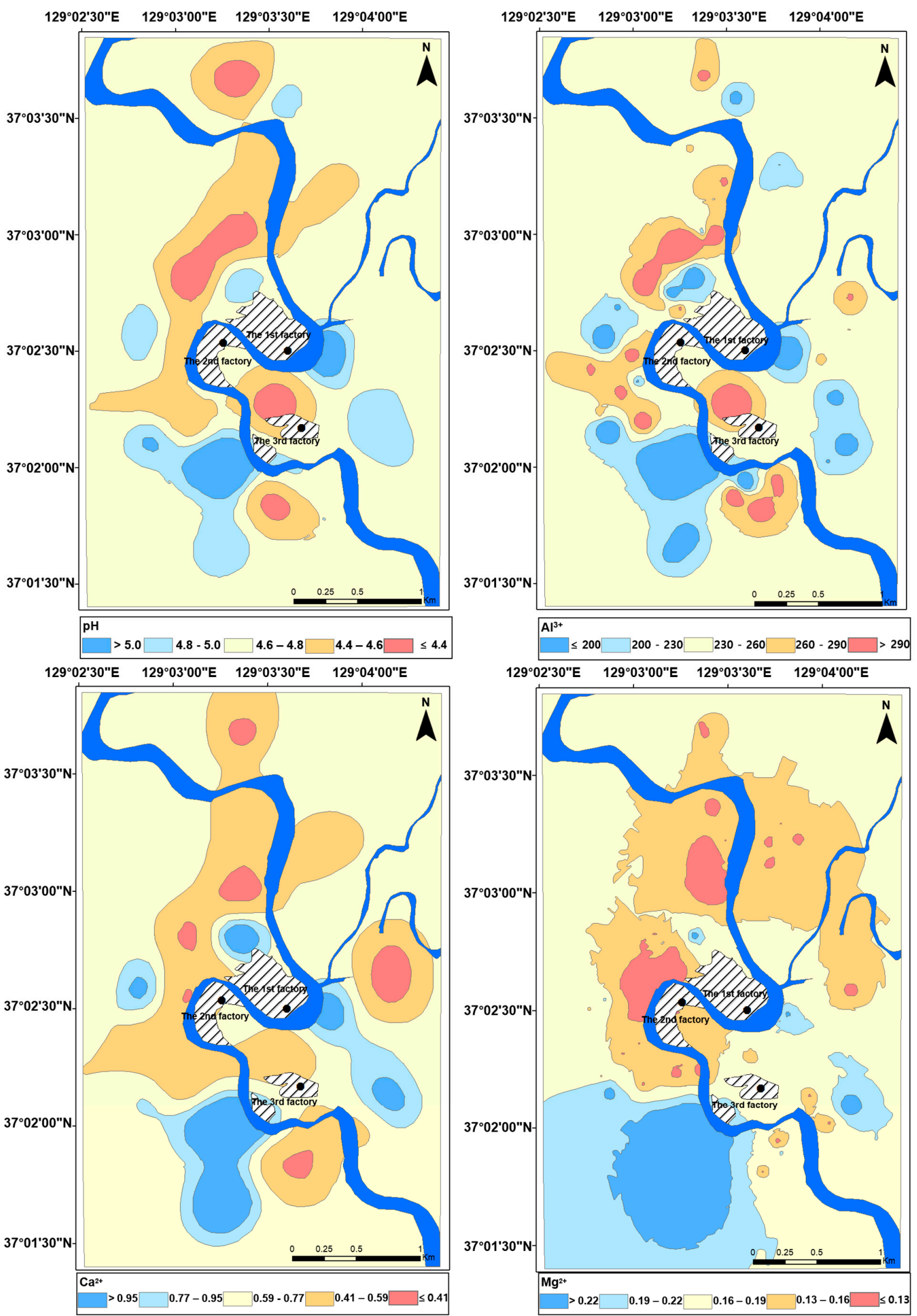

Figure 6. Spatial distribution of soil $\mathrm{pH}$ and $\mathrm{Ca}^{2+}, \mathrm{Mg}^{2+}$, and $\mathrm{Al}^{3+}$ contents of soil in the study area. 
Soil $\mathrm{pH}$ tended to be relatively low in the northern and western directions of the three factories, the area surrounded by those factories, and the southern direction of the third factory, whereas it was relatively high in the southwestern and northeastern directions of the third factory (Figure 6).

The $\mathrm{Ca}^{2+}$ and $\mathrm{Mg}^{2+}$ content showed trends similar to that of the $\mathrm{pH}$, while $\mathrm{Al}^{3+}$ content represented a reverse trend (Figure 6).

The physic-chemical properties of the soil were compared with those of the reference site and among the degrees of damage to the vegetation (Figure 7). The $\mathrm{pH}$ and $\mathrm{Ca}^{2+}, \mathrm{Mg}^{2+}$, and available phosphorus contents were lower than those in the reference site, whereas the total nitrogen content was vice versa. However, organic matter and $\mathrm{Al}^{3+}$ content did not show any significant difference between both sites. On the other hand, $\mathrm{pH}$ and $\mathrm{Ca}^{2+}$ and $\mathrm{Mg}^{2+}$ contents showed significant difference among the degrees of damage to the vegetation, but the other factors did not show any significant differences among the degrees of damage.
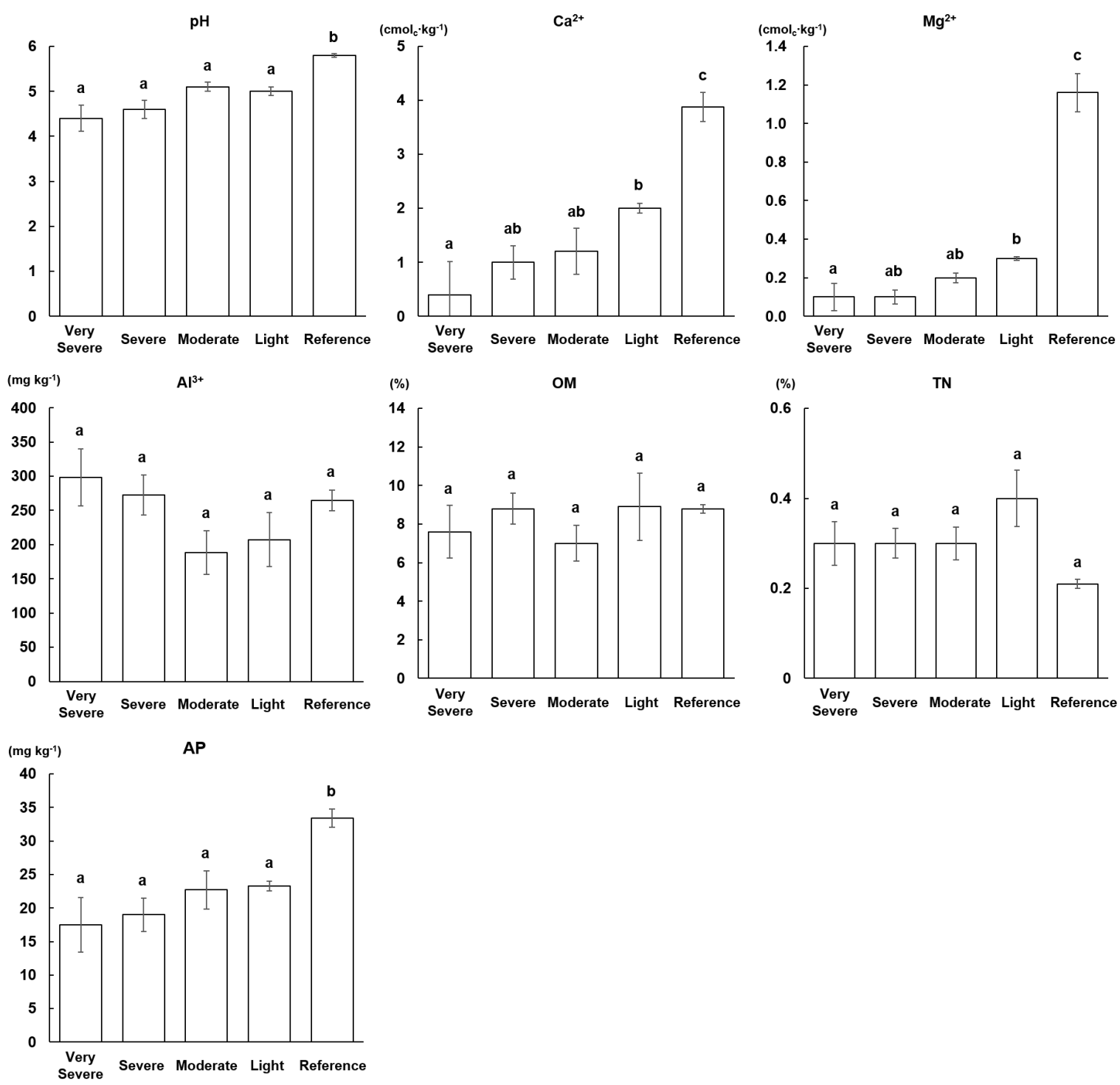

Figure 7. A comparison of the physic-chemical properties of the soil among damage degrees of vegetation and with that of the reference site. Very severe, severe, moderate, and light indicate damage degree and reference indicates the unpolluted site selected for comparison. OM: organic matter; TN: Total nitrogen; AP: available phosphorus. Each bar was expressed with mean and standard error of mean. Tukey's honestly significant difference (HSD) test was conducted on each of the parameters that show a statistically significant difference among the four types of damage degrees at $\alpha=0.05$; the means with the same alphabetical character (in superscript), for each parameter, were not different from each other. 


\subsection{Species Composition}

As the result of stand ordination, arrangement of stands reflected vegetation damage (Figure 8). The reference stands were arranged on the left on the AXIS I and very severely or severally damaged stands on the right, and moderately and lightly damaged stands were arranged between both groups. Moderately and lightly damaged stands tended to be arranged depending on the topographical position as P. densiflora stands, Q. Mongolica stands, and stands established in the valley were arranged in the mentioned order as moves from bottom upward on the AXIS II. Meanwhile, cut slope stands were arranged in the left part on the AXIS I like the reference stands but separated from them on the AXIS II.

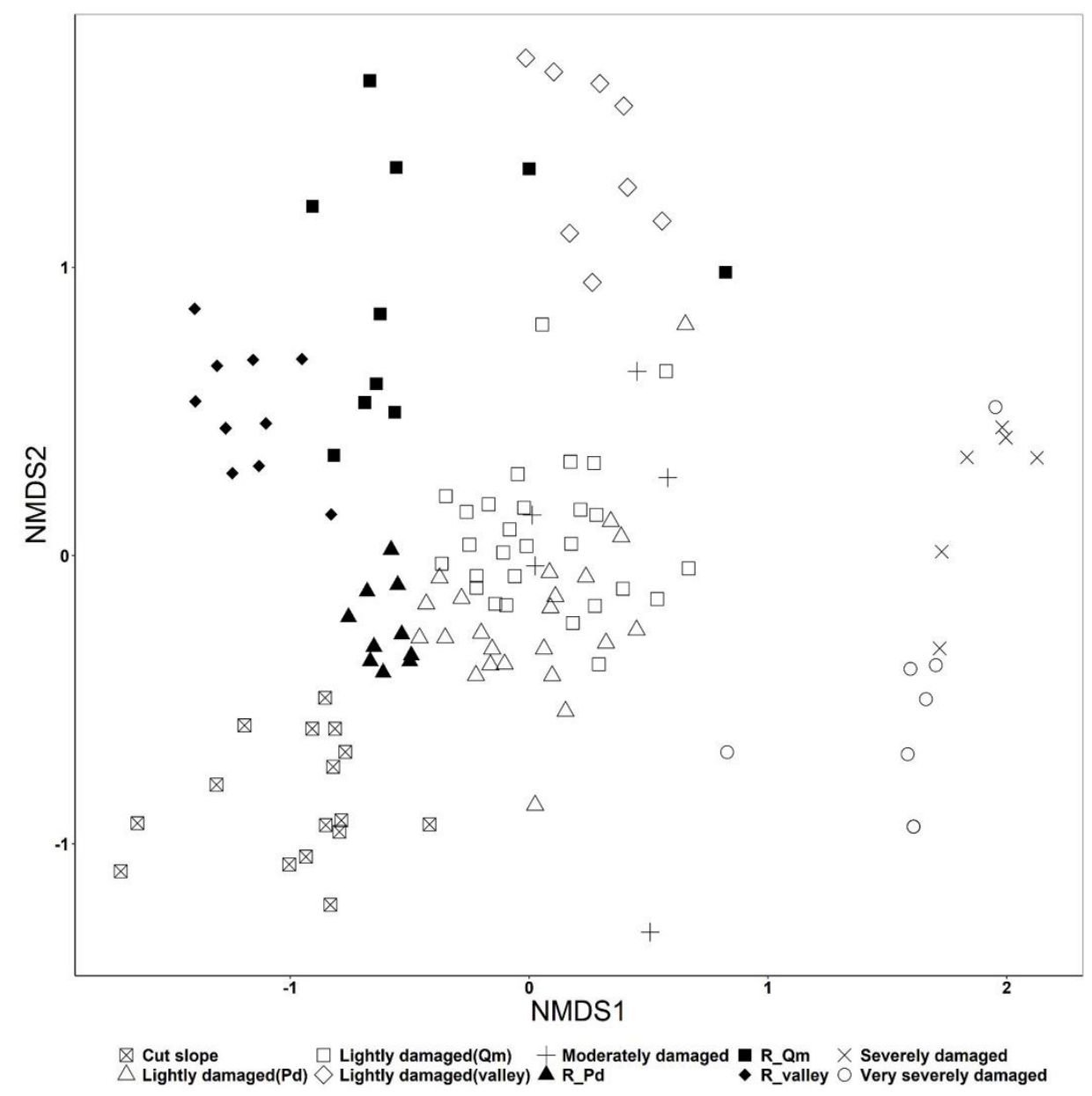

Figure 8. Ordination of vegetation stands established around the Seokpo smelter and on the natural reference forest, Uljin Forest Genetic Resources Conservation Reserve, central eastern Korea. Legends expressed as damage degree represent the damaged stands established around the Seokpo smelter. R_Pd: Pinus densiflora stands established in the reference site; R_Qm: Quercus mongolica stands established in the reference site; R_Valley: stands established in the reference site; Cut slope: stands established on the incised slope along the forest road ( $p=0.001$, stress $=0.1702836)$.

\subsection{Species Diversity}

As a result of comparing the species diversity by the species rank-dominance curve, the species diversity of the damaged sites was lower than that in the reference sites (Figure 9). In the damaged sites, species diversity tended to decrease in proportion to the damage degree (Figure 8). The species diversity was also dominated by the topographic condition and thus high in the vegetation established in the valley and low in the pine forest on the ridge, and the species diversity of broad-leaved forests on the mountain slope was located between both vegetation types (Figure 9). 


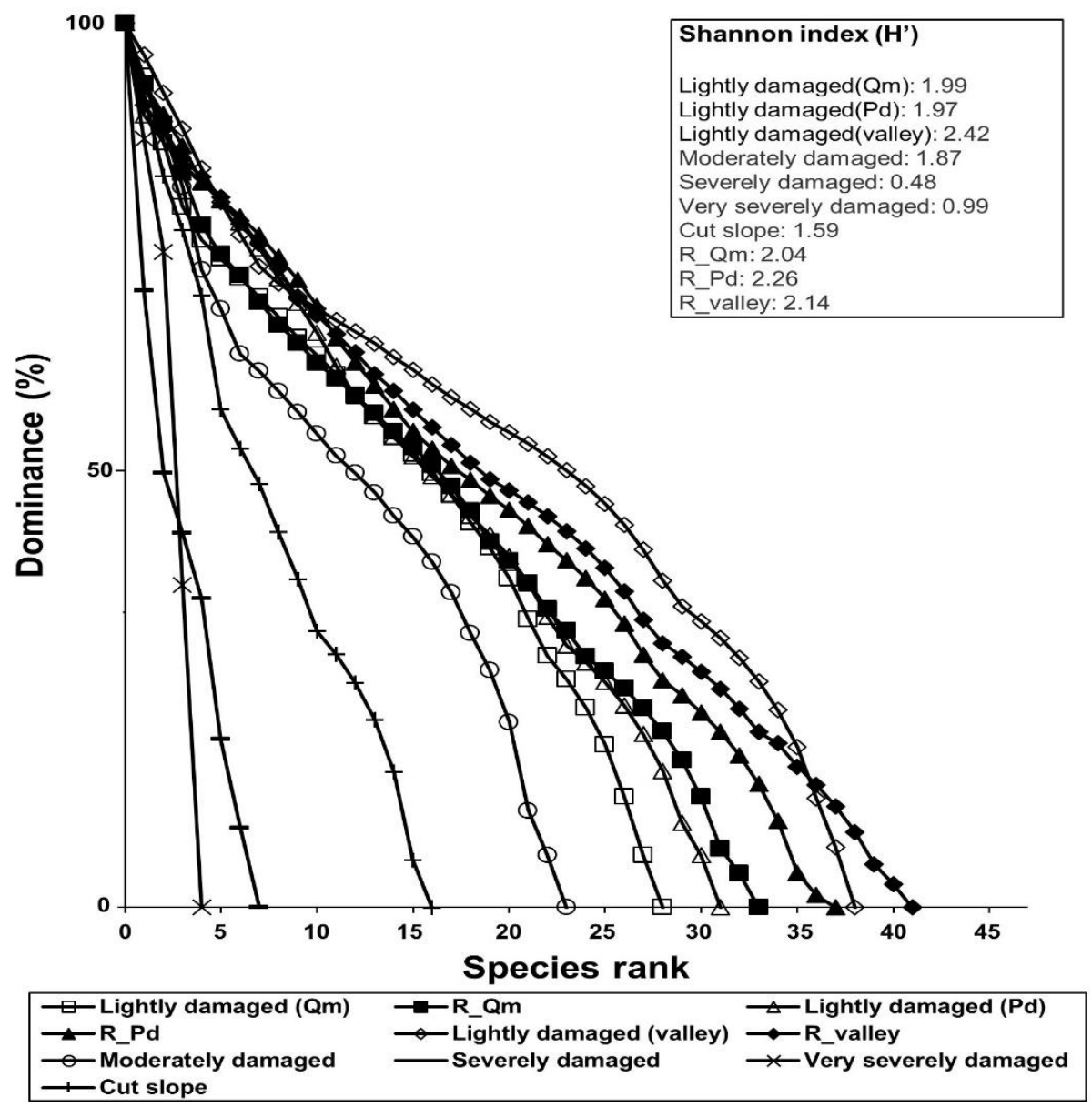

Figure 9. Species rank-dominance curves of vegetation stands established around the Seokpo smelter and on the natural reference forest, Uljin Forest Genetic Resources Conservation Reserve, southeastern Korea. Legends are the same as those in Figure 8.

\subsection{Selection of Plant Species for Vegetation Restoration}

We selected disappeared, tolerant, and early successional species by applying the indicator species analysis (Tables 1-4). First, we selected species to be introduced for vegetation restoration by comparing all vegetation data between polluted and natural reference sites and cut slope. We selected species which appear in the natural reference site but do not appear in the polluted site as the disappeared species. The disappeared species mean species that should be introduced for vegetation restoration. We selected species which showed the reverse trend to the disappeared species as the tolerant species. The species which appear characteristically on the cut slope were selected as the early successional species. Ecological restoration should copy the environment by studying a system of the integrate nature. However, considering the environmental condition of this area where air and soil pollution continues and vegetation is so severely damaged that bare ground can appear and severe soil erosion occurs, we added the tolerant and early successional species in our restoration plan. In addition, we added the plant species to be introduced by referring to the existing research data conducted around this study area $[69,70]$ to enhance the stability of the restoration plan. 
Table 1. The result of indicator species analysis for selecting the disappeared species, tolerant species to the polluted environment, and early successional species based on data collected in all study sites. Cut slope: early successional species; Severe, Moderate, Light: tolerant species in severely, moderately, and lightly damaged sites, respectively; Valley: tolerant species in valley; Reference(Pd), Reference(Qm), Reference(VA): disappeared species in the natural reference sites of Pinus densiflora forest, Quercus mongolica forest, and valley forest, respectively.

\begin{tabular}{cccc}
\hline Species Name & Site Type & Stat & $p$-Value \\
\hline Betula schmidtii & Cut slope & 0.675 & $0.001^{* * *}$ \\
Calamagrostis arundinacea & Cut slope & 0.787 & $0.001^{* * *}$ \\
Lindera obtusiloba & Moderate & 0.802 & $0.001^{* * *}$ \\
Tripterygium regelii & Moderate & 0.436 & $0.009^{* *}$ \\
Rhododendron schlippenbachii & Light & 0.463 & $0.006^{* *}$ \\
Actinidia arguta & Valley & 0.525 & $0.002^{* *}$ \\
Aralia elata & Valley & 0.482 & $0.012^{*}$ \\
Deutzia parviflora & Valley & 0.502 & $0.002^{* *}$ \\
Fraxinus rhynchophylla & Valley & 0.414 & $0.026^{*}$ \\
Schisandra chinensis & Valley & 0.396 & $0.037^{*}$ \\
Athyrium yokoscense & Very severe & 0.904 & $0.001^{* * *}$ \\
Miscanthus sinensis var. purpurascens & Severe & 0.952 & $0.001^{* * *}$ \\
Betula chinensis & Reference(Pd) & 0.496 & $0.004^{* *}$ \\
Disporum smilacinum & Reference(Pd) & 0.585 & $0.001^{* * *}$ \\
Fraxinus sieboldiana & Reference(Pd) & 0.677 & $0.001^{* * *}$ \\
Aster scaber & Reference(Qm) & 0.513 & $0.007^{* *}$ \\
Athyrium vidalii & Reference(Qm) & 0.449 & $0.005^{* *}$ \\
Callicarpa japonica & Reference(Qm) & 0.470 & $0.005^{* *}$ \\
Carex siderosticta & Reference(Qm) & 0.440 & $0.007^{* *}$ \\
Hydrangea serrata f. acuminata & Reference(Qm) & 0.425 & $0.016^{*}$ \\
Potentilla freyniana & Reference(Qm) & 0.564 & $0.002^{* *}$ \\
Styrax obassis & Reference(Qm) & 0.417 & $0.030^{*}$ \\
Carex humilis var. nana & Reference(VA) & 0.441 & $0.006^{* *}$ \\
Cornus controversa & Reference(VA) & 0.874 & $0.001^{* * *}$ \\
Juglans mandshurica & Reference(VA) & 0.402 & $0.050^{*}$ \\
\hline
\end{tabular}

*** significant at $0.1 \%$ level, ${ }^{* *}$ significant at $1 \%$ level, ${ }^{*}$ significant at $5 \%$ level.

Table 2. The result of indicator species analysis for selecting the disappeared species and tolerant species to the polluted environment based on data collected in both polluted and natural Pinus densiflora forests. Polluted: tolerant species in the polluted site of Pinus densiflora forest; Reference: disappeared species in the natural reference site of Pinus densiflora forest.

\begin{tabular}{cccc}
\hline Species Name & Site Type & Stat & $p$-Value \\
\hline Athyrium yokoscense & Polluted & 0.315 & $0.039 *$ \\
Lindera obtusiloba & Polluted & 0.447 & $0.004^{* *}$ \\
Miscanthus sinensis var. purpurascens & Polluted & 0.333 & $0.040^{*}$ \\
Quercus mongolica & Polluted & 0.446 & $0.011^{*}$ \\
Rhododendron schlippenbachii & Polluted & 0.461 & $0.024^{*}$ \\
Atractylodes ovata & Reference & 0.418 & $0.033^{*}$ \\
Betula chinensis & Reference & 0.391 & $0.034^{*}$ \\
Carex humilis var. nana & Reference & 0.704 & $0.001^{* *}$ \\
Dendranthema zawadskii var. latilobum & Reference & 0.419 & $0.031^{*}$ \\
Disporum smilacinum & Reference & 0.568 & $0.001^{* * *}$ \\
Fraxinus sieboldiana & Reference & 0.533 & $0.002^{* * *}$ \\
Lespedeza bicolor & Reference & 0.886 & $0.001^{* * *}$ \\
Rhododendron micranthum & Reference & 0.634 & $0.001^{* * *}$ \\
\hline
\end{tabular}

*** significant at $0.1 \%$ level, ${ }^{* *}$ significant at $1 \%$ level, ${ }^{*}$ significant at $5 \%$ level. 
Table 3. The result of indicator species analysis for selecting the disappeared species and tolerant species to the polluted environment based on data collected in both polluted and natural Quercus mongolica forests. Polluted: tolerant species in the polluted site of Quercus mongolica forest; Reference: disappeared species in the natural reference site of Quercus mongolica forest.

\begin{tabular}{cccc}
\hline Species Name & Site Type & Stat & $p$-Value \\
\hline Athyrium yokoscense & Polluted & 0.310 & $0.034^{*}$ \\
Fraxinus sieboldiana & Polluted & 0.419 & $0.008^{* *}$ \\
Lindera obtusiloba & Polluted & 0.514 & $0.001^{* * *}$ \\
Rhododendron schlippenbachii & Polluted & 0.498 & $0.004^{* *}$ \\
Acer pseudosieboldianum & Reference & 0.397 & $0.006^{* *}$ \\
Ainsliaea acerifolia & Reference & 0.543 & $0.001^{* * *}$ \\
Artemisia keiskeana & Reference & 0.449 & $0.002^{* *}$ \\
Aster scaber & Reference & 0.407 & $0.018^{*}$ \\
Athyrium vidalii & Reference & 0.351 & $0.015^{*}$ \\
Atractylodes ovata & Reference & 0.448 & $0.001^{* * *}$ \\
Betula schmidtii & Reference & 0.380 & $0.012^{*}$ \\
Callicarpa japonica & Reference & 0.419 & $0.015^{*}$ \\
Carex humilis var. $n a n a$ & Reference & 0.419 & $0.016^{*}$ \\
Carex siderosticta & Reference & 0.341 & $0.002^{* *}$ \\
Hydrangea serrata f. acuminata & Reference & 0.360 & $0.015^{*}$ \\
Lespedeza bicolor & Reference & 0.306 & $0.027^{*}$ \\
Polystichum tripteron & Reference & 0.391 & $0.017^{*}$ \\
Potentilla freyniana & Reference & 0.645 & $0.001^{* * *}$ \\
Rubus crataegifolius & Reference & 0.419 & $0.015^{*}$ \\
\hline
\end{tabular}

*** significant at $0.1 \%$ level, ${ }^{* *}$ significant at $1 \%$ level, ${ }^{*}$ significant at $5 \%$ level.

Table 4. The result of indicator species analysis for selecting the disappeared species and tolerant species to the polluted environment based on data collected in both polluted and natural valley forests. Pol-luted: tolerant species in the polluted site of valley forest; Reference: disappeared species in the natural reference site of valley forest.

\begin{tabular}{cccc}
\hline Species Name & Site Type & Stat & $p$-Value \\
\hline Actinidia arguta & Polluted & 0.423 & $0.028^{*}$ \\
Athyrium yokoscense & Polluted & 0.548 & $0.019 *$ \\
Lindera obtusiloba & Polluted & 0.655 & $0.001^{* * *}$ \\
Miscanthus sinensis var. purpurascens & Polluted & 0.554 & $0.028^{*}$ \\
Quercus mongolica & Polluted & 0.432 & $0.038^{*}$ \\
Cornus controversa & Reference & 0.759 & $0.001^{* *}$ \\
Rhododendron mucronulatum & Reference & 0.496 & $0.048^{*}$ \\
\hline
\end{tabular}

*** significant at $0.1 \%$ level, ${ }^{*}$ significant at $5 \%$ level.

\subsection{Zonning and Design for Restorative Treatment}

The spatial range for which the restoration was required was restricted within the first ridge from the pollution source, considering the impact extent of the air pollution. We divided the district for restoration into four zones of very severely, severely, moderately, and lightly damaged zones based on the damage degree (Table 5) and three zones of ridge, slope, and valley based on the topographic conditions (Table 6) [13]. 
Table 5. Level and method of restoration recommended based on a diagnostic evaluation of the forest ecosystem around Seokpo zinc smelter, central eastern Korea.

\begin{tabular}{|c|c|c|c|}
\hline Damaged Degree & Vegetation Status & Soil pH & Restoration Method \\
\hline Very severe & $\begin{array}{c}\text { Grassland with low coverage or } \\
\text { bare ground }\end{array}$ & 4.4 & $\begin{array}{c}\text { Soil amelioration: dolomite } 4.5 \text { ton } / \text { ha }+ \text { organic } \\
\text { fertilizer } 2.3 \text { ton } / \text { ha } \\
\text { Introduction of plants forming all layers } \\
\text { of vegetation }\end{array}$ \\
\hline Severe & $\begin{array}{l}\text { Canopy layer disappeared and } \\
\text { shrub and herb layers are poor }\end{array}$ & 4.6 & $\begin{array}{l}\text { Soil amelioration: dolomite } 3.0 \text { ton/ha + organic } \\
\text { fertilizer } 1.5 \text { ton/ha } \\
\text { Introduction of plants forming canopy tree, shrub, } \\
\text { and herb layers }\end{array}$ \\
\hline Moderate & $\begin{array}{l}\text { All vegetation strata exist but } \\
\text { coverage is poor }\end{array}$ & 5.1 & $\begin{array}{l}\text { Soil amelioration: dolomite } 1.5 \text { ton } / \text { ha }+ \text { organic } \\
\text { fertilizer } 0.8 \text { ton } / \text { ha } \\
\text { Introduction of plants forming shrub and } \\
\text { herb layers }\end{array}$ \\
\hline Light & $\begin{array}{l}\text { Development of undergrowth } \\
\text { is poor }\end{array}$ & 5.0 & $\begin{array}{l}\text { Soil amelioration: dolomite } 1.0 \text { ton } / \text { ha }+ \text { organic } \\
\text { fertilizer } 0.5 \text { ton } / \text { ha } \\
\text { Vegetation restoration is left to passive restoration }\end{array}$ \\
\hline
\end{tabular}

Table 6. Species to be introduced for restoration by layer of vegetation in each topographic condition. This species information was prepared by incorporating disappeared species compared with the natural reference site, tolerant species to the polluted environment, and early successional species. In very severely and severely damaged zones, plant species forming all layers of vegetation stratification including canopy tree, understory tree, shrub, and herb layers are recommended for restoration. Plant species forming shrub and herb layers are recommended in moderately damaged zone. Passive restoration is recommended in lightly damaged zone. Vegetation type, such as Korean red pine forest established as an edaphic climax type on the upper slope, usually lacks understory tree layer due to topographic condition, which is dry and infertile.

\begin{tabular}{|c|c|c|c|}
\hline Vegetation Stratum & Ridge & Slope & Valley \\
\hline Canopy tree layer & $\begin{array}{l}\text { Betula schmidtii } \\
\text { Betula chinensis * } \\
\text { Pinus densiflora } \\
\text { Quercus variabilis } \\
\text { etc. }\end{array}$ & $\begin{array}{l}\text { Betula davurica* } \\
\text { Betula schmidtii* } \\
\text { Quercus aliena* } \\
\text { Quercus mongolica } \\
\text { Quercus variabilis } \\
\text { etc. }\end{array}$ & $\begin{array}{c}\text { Acer pictum subsp. Mono } \\
\text { Cornus controversa } \\
\text { Fraxinus rhynchophylla } \\
\text { Juglans mandshurica } \\
\text { Quercus mongolica } \\
\text { etc. }\end{array}$ \\
\hline $\begin{array}{l}\text { Understory tree } \\
\text { layer }\end{array}$ & Lindera obtusiloba ${ }^{* *}$ & $\begin{array}{l}\text { Acer pseudosieboldianum * } \\
\text { Fraxinus rhynchophylla * } \\
\text { Lindera obtusiloba } \\
\text { etc. }\end{array}$ & $\begin{array}{l}\text { Lindera obtusiloba }{ }^{* *} \\
\text { Magnolia sieboldii } \\
\text { etc. }\end{array}$ \\
\hline Shrub layer & $\begin{array}{c}\text { Fraxinus sieboldiana }{ }^{*} \\
\text { Lespedeza bicolor } \\
\text { Lespedeza cyrtobotrya } \\
\text { R* } \\
\text { Rhododendron micranthum }{ }^{* *} \\
\text { Rhododendron mucronulatum }{ }^{*} \\
\text { Rhododendron schlippenbachii } \\
\text { Toxicodendron trichocarpum } \\
\text { ** } \\
\text { Vaccinium hirtum var. koreanum }{ }^{* *} \\
\text { Weigela florida }{ }^{*} \\
\text { etc. }\end{array}$ & $\begin{array}{l}\text { Callicarpa japonica } \\
\text { Clerodendrum trichotomum } \\
\text { Fraxinus sieboldiana } \\
\text { Lespedeza bicolor }^{*} \\
\text { Lespedeza maximowiczii }^{*} \\
\text { Lindera glauca }^{*} \\
\text { Rhododendron mucronulatum } \\
\text { Rhododendron schlippenbachii } \\
\text { ** } \\
\text { Rubus crataegifolius }{ }^{*} \\
\text { Toxicodendron trichocarpum } \\
\text { Symplocos sawafutagi } \\
\text { *accinium hirtum var. } \\
\text { koreanum } \\
\text { etc. }\end{array}$ & $\begin{array}{c}\text { Alangium platanifolium var. } \\
\text { trilobum } \\
\text { Cimicifuga simplex } \\
\text { Corylus heterophylla } \\
\text { Rhododendron mucronulatum } \\
\text { Styrax obassia } \\
\text { Weigela subsessilis } \\
\text { etc. }\end{array}$ \\
\hline
\end{tabular}


Table 6. Cont.

\begin{tabular}{|c|c|c|c|}
\hline Vegetation Stratum & Ridge & Slope & Valley \\
\hline Herb layer & $\begin{array}{c}\text { Arundinella hirta }{ }^{* *} \\
\text { Athyrium yokoscense }{ }^{* *} \\
\text { Carex humilis var. nana } \\
\text { Carex siderosticta* } \\
\text { Dendranthema zawadskii var. latilobum * } \\
\text { Disporum smilacinum }{ }^{*} \\
\text { Melampyrum roseum } \\
\text { * } \\
\text { Miscanthus sinensis var. purpurascens }{ }^{* * *} \\
\text { Pteridium aquilinum var. latiusculum } \\
\text { Spodiopogon sibiricus } \\
\text { etc. }\end{array}$ & $\begin{array}{c}\text { Ainsliaea acerifolia * } \\
\text { Artemisia keiskeana * } \\
\text { Aster scaber } \\
\text { Athyrium vidalii } \\
\text { Athyrium yokoscense } \\
\text { Atractylodes ovata } \\
\text { Calamagrostis arundinacea } \\
\text { Carex humilis var. nana } \\
\text { Carex siderosticta } \\
\text { * } \\
\text { Disporum smilacinum } \\
\text { Hydrangea serrata f. acuminata } \\
\text { Polystichum tripteron * } \\
\text { Potentilla freyniana } \\
\text { etc. }\end{array}$ & $\begin{array}{c}\text { Actinidia arguta * } \\
\text { Angelica decursiva } \\
\text { Athyrium yokoscense ** } \\
\text { Carex humilis var. nana * } \\
\text { Cimicifuga dahurica * } \\
\text { Corydalis speciose * } \\
\text { Dryopteris crassirhizoma } \\
\text { Isodon excisus * } \\
\text { Miscanthus sinensis var. } \\
\text { purpurascens ** } \\
\text { Persicaria filiformis } \\
\text { Polystichum tripteron } \\
\text { Scutellaria dependens * } \\
\text { etc. }\end{array}$ \\
\hline
\end{tabular}

$*, * *$ and ${ }^{* * *}$ indicate disappeared species, tolerant species, and pioneer species, respectively.

The restorative treatment was determined by reflecting the damaged level of vegetation and soil acidification. In very severely damaged zones, dolomite of 4.5 ton/ha and organic fertilizer of 2.25 ton/ha were recommended for soil amelioration. Plant species forming all layers of vegetation stratification, including canopy tree, understory tree, shrub, and herb layers, were recommended for vegetation restoration. In severely damaged zones, dolomite of 3.0 ton/ha and organic fertilizer of 1.5 ton/ha were recommended for soil amelioration. Plant species forming all layers of vegetation stratification were recommended for vegetation restoration, such as in the case of the very severely damaged zone. In moderately damaged zones, dolomite of 1.5 ton/ha and organic fertilizer of 0.75 ton/ha were recommended for soil amelioration. For restoring vegetation, plant species forming shrub and herb layers of vegetation stratification were recommended. Plant species forming shrub and herb layers were recommended in the moderately damaged zone. In the lightly damaged zone, dolomite of 1.0 ton/ha and organic fertilizer of 0.5 ton/ha were recommended for soil amelioration. Passive restoration was recommended for restoring vegetation.

In this restoration plan, we did not recommend for plant species forming the understory tree layer that vegetation to be introduced on the upper slope and ridge, as vegetation established there usually lacks the layer.

\section{Discussion}

\subsection{The Effects of Air Pollution on Forest Ecosystems}

Air pollution and atmospheric deposition emitted from industrial facilities have adverse effects on tree and forest health. Growing awareness of the air pollution effects on forests has, from the early 1980s on, led to intensive forest damage research and monitoring. This has fostered air pollution control, especially in developed countries, and also, to a smaller extent, in developing countries. At several forest sites, particularly in developed countries, there are the first indications of the recovery of forest soil and tree conditions that may be attributed to improved air quality [4,71]. This caused a decrease in the attention paid by the public to the air pollution effects on forests. However, air pollution continues to affect the structure and functioning of forest ecosystems just as when this study was conducted.

Air pollutants may impact trees as both wet and dry deposition. Wet deposition comprises rain, hail, and snow and is largely determined by atmospheric processes. Dry deposition consists of gases, aerosols, and dust and is largely influenced by the physical and chemical properties of the receptor surface. Forests receive higher deposition loads than open fields, depending on the tree species and canopy structure. A higher roughness of the canopy causes higher air turbulences and more intensive interactions between the 
air and the foliage. The interception of pollutants by the foliage in turn is determined by such factors as leaf area index, leaf shape, leaf surface roughness, and stomata size. Dry deposition accumulated on the foliage is washed off by precipitation and enhances the deposition under the canopy (throughfall) in comparison to deposition in an open field (bulk deposition). Moreover, throughfall is influenced by two components of canopy exchange: canopy leaching and canopy uptake of elements. The main air pollutants involved in forest damage are sulfur compounds, nitrogen compounds, ozone, and heavy metals [72-76].

Sulfur dioxide $\left(\mathrm{SO}_{2}\right)$ was the first air pollutant found to cause damage to trees [77]. Its air concentrations increased rapidly when it was released into the atmosphere by the combustion of fossil fuels during the course of industrialization. While damaging trees directly via their foliage, $\mathrm{SO}_{2}$ also reacts with water in the atmosphere to form sulfurous acid $\left(\mathrm{H}_{2} \mathrm{SO}_{3}\right)$ and sulfuric acid $\left(\mathrm{H}_{2} \mathrm{SO}_{4}\right)$, thus contributing to the formation of acid precipitation and hence to the indirect damage of trees [72,73]. In Korea, forest decline has usually occurred around industrial areas, and $\mathrm{SO}_{2}$ has played a leading role $[7,8,13]$. However, Korea has shown declining trends in $\mathrm{SO}_{2}$ concentrations in recent years [4].

Nitrogen oxides (NOx) are released into the atmosphere in the course of various combustion processes in which nitrogen $(\mathrm{N})$ in the air is oxidized mainly to nitrogen monoxide (NO), with a small admixture of nitrogen dioxide $\left(\mathrm{NO}_{2}\right)$. In daylight, $\mathrm{NO}$ is easily converted to $\mathrm{NO}_{2}$ by photochemical reactions involving hydrocarbons present in the air. Both gases, especially NO, are also produced biologically by soil bacteria during nitrification, denitrification, and decomposition of nitrite $\left(\mathrm{NO}_{2}{ }^{-}\right)$[78]. These substances are gaseous and act on trees as dry deposition directly via the foliage. Some of them are acidifying and lead - by means of chemical reactions with water in the atmosphere-to acid precipitation. Acidifying compounds such as $\mathrm{SO}_{2}, \mathrm{NOx}$, and $\mathrm{NH}_{3}$, however, enhance the concentrations of protons and form sulfuric acid, nitric acid $\left(\mathrm{HNO}_{3}\right)$, ammonium $\left(\mathrm{NH}_{4}\right)$, and nitrate $\left(\mathrm{NO}_{3}\right)[73,74,79]$.

Heavy metals result from most combustion processes and from many industrial production processes. They are released into the atmosphere by means of dust and, at high temperatures, also as gases. The main heavy metals considered to be detrimental to forest health are cadmium $(\mathrm{Cd})$, lead $(\mathrm{Pb})$, mercury $(\mathrm{Hg})$, cobalt $(\mathrm{Co})$, chromium $(\mathrm{Cr})$, copper $(\mathrm{Cu})$, nickel $(\mathrm{Ni})$, and zinc $(\mathrm{Zn})$. However, largely because of their impacts on human health, heavy metal emissions have been reduced greatly within the last 3 decades in many industrialized countries [80-82].

\subsection{Damage Status to Forest Ecosystem around Seokpo Smelter}

Vegetation in places close to smelters has been so severely damaged that only a few plants, such as Athyrium yokoscense (FR. Et SAV.) H.CHRIST, Miscanthus sinensis var. purpurascens RENDLE, and Pteridium aquilinum var. latiusculum (DESV.) UNDERW, sporadically exist; otherwise all of them have disappeared. As the distance from the smelter become farther, the damage decreases, resulting in shrubland and forest (Figures 4 and 5). The spatial distribution of vegetation in industrial areas usually reflects the degree of pollution damage $[4,7,8,12]$. If a forested ecosystem is being affected by air pollution, then the canopy stratum is generally impacted first and is stripped away. As canopy trees decline, shrubs and then the ground vegetation are affected. This syndrome of the sequential death of the horizontal strata of the terrestrial vegetation, described as a "peeling" of "layered vegetation effect" by [62], was observed clearly in this area (Figure 5).

Forests appeared as two types depending on the damage degree. Forests with moderate damage show poor development of vegetation stratum, while forests with light damage show visible damage in appearance and poor development of undergrowth (Figure 5). The damage was also reflected in species composition (Figure 8) and species diversity (Figure 9), showing a clear difference in species composition and species diversity compared to the reference area. 
The soil is acidified and has a lower calcium and magnesium content compared to the reference area, while the aluminum content was higher in very severely damaged sites (Figure 6).

Synthesized results obtained from the diagnostic assessments on vegetation damage and soil acidification in the forest ecosystem around the Seokpo zinc smelter show that vegetation damage was so severe that denuded ground appeared throughout wide areas, and soil acidification was also relatively severe. In this respect, active restoration is required urgently to prevent follow-up damage, such as landslides [83-85]. However, the damage decreased with increasing distance from the pollution source and was restricted within the first ridge from the source. The results of this diagnostic assessment could help to determine the spatial range and level of restoration.

In the case of the Yeocheon industrial complex, passive restoration occurred in forests around industrial complexes [4], but the speed was slower than in the case of the Ulsan industrial complex where active restoration was applied [8]. In active restoration, dolomite and sludge treatment neutralized acidic soil and supplemented nutrients, thereby facilitating plant growth and contributing to the restorative effects [8]. In addition, the tolerant species, which was selected through field surveys and laboratory experiments, was well established and contributed to achieve successful restoration $[8,36]$.

\subsection{Necessity and Recommendation of Ecological Restoration}

In Korea, most industrial complexes are located on the coastal areas $[4,7,8]$. However, the area where this study was conducted is uniquely located on a small mountain village. Most of this area is composed of a mountainous area with a steep slope, and it is therefore not easy to develop. Therefore, the nature is well conserved. The mountainous land of this area is very steep and shallow in soil depth. Thus, Korean red pine forest, which is adapted well to the dry and infertile environment, dominates the vegetation of this area. However, deciduous broad-leaved forests suitable for the climate condition of this region and the environmental characteristics of each site are well developed in lowlands below midslope, including mountainous valleys. The river that runs through this area corresponds to the upstream section of the Nakdong River, one of the longest rivers in Korea. As Korea is a mountainous nation where more than $65 \%$ of the total national territory is composed of mountainous areas, most riparian zones, including floodplains of rivers, are transformed into agricultural lands and urbanized areas, leaving few integrate rivers equipped with aquatic and riparian zones in the plains and lands with a gentle slope. However, as this area is not easy to develop due to the environmental characteristics composed of steep mountainous areas; the river also remains an almost completely intact status.

However, air pollutants emitted from the Seokpo smelter have destroyed forest vegetation established in the basin of this river, even leading to landslides. Therefore, its impact poses a great threat to the river ecosystem conserved so well. Considering these facts comprehensively, the restoration of the damaged forest ecosystem is absolutely necessary and urgently required. In particular, countermeasures such as restoring forests are important for ensuring future ecosystem services [7,8,13].

The continual growth of the human population and human land uses leads to declines in the quality of the environment. Further, the natural landscapes that provide many ecosystem services are being rapidly converted to agricultural, industrial, and urban areas, and even wastelands. The biodiversity and habitability of the planet are now more threatened than ever before. Therefore, it is imperative that degraded land be rehabilitated and that adjoining natural landscapes be protected. However, it is clear that degradation thresholds have been crossed in many habitats, and succession alone cannot restore viable and desirable ecosystems without intervention [86]. As was shown in our results (Figures 4 and 5), the forest has degraded through shrubland or grassland to denuded land, eventually producing continual landslides. In addition, the soil is acidified and becoming non-nutritive (Figure 6). Thus restoration actions are urgently required to prevent more land degradation. 
To restore degraded ecosystems, in particular those degraded by pollution, we need to apply soil ameliorators, including dolomite $[6,8,13,87,88]$. Although these soil amendments contributed to improving the polluted environment and thereby achieved successful revegetation in the case of Sudbury [6], they may cause other problems, such as ground water pollution and eutrophication $[73,89,90]$. In this respect, we recommend planting tolerant plants or applying fertilizer plants rather than applying soil amendments as a restorative treatment in all cases [8].

\subsection{Soil Amelioration for Restoration}

The atmospheric environment in the industrial areas in Korea is improving due to a decrease in the emission of air pollutants [4]. However, the polluted soil has not improved so easily $[7,8]$. In fact, polluted soil usually provides the major challenge to most restoration programs $[8,13,29,35]$. Therefore, soil amendment was planned as a preparation for restoration. The soil amelioration focused on the neutralization of acidic soil and the enhancement of fertility. Previous research showed that dolomite was a superior ameliorator compared to lime [15], and it is also generally used [8,16]. The amount of dolomite applied was calculated with an equation being applied to determine the amount of dolomite required to improve varying soil $\mathrm{pH}$ to 5.5 [15]. In the present situation, the amounts of dolomite required were $4.5,3.0,1.5$, and 1.0 ton/ha in very severely, severely, moderately, and lightly damaged zones, respectively (Table 1). These amounts were smaller than those used in the Sudbury region of Canada [16] and the Ulsan industrial area of Korea [13].

Soil neutralized by the addition of dolomite stimulates activities of soil microorganisms and enhances nutrient availability through the promoted decomposition of organic matter [8,91]. Organic fertilizer also may ameliorate acidified soil by raising $\mathrm{pH}$ and adding macronutrients, including phosphorus, which is often a limiting nutrient in acidic soil [13,88,92].

Aluminum toxicity results in rapid inhibition of root growth due to the impedance of both cell division and elongation [93-95], reduction of soil volume explored by the root system, and direct interference with the uptake of ions such as calcium and phosphate across the cell membrane of damaged roots [96,97]. The deficiency in soil nutrients, such as $\mathrm{P}, \mathrm{Ca}^{2+}$, and $\mathrm{Mg}^{2+}$, exacerbate the problem of inefficient nutrient uptake due to restricted root growth and root damage [98,99].

Additions of undecomposed plant materials, such as pruning, to acid soils often increase soil $\mathrm{pH}$, decrease $\mathrm{Al}^{3+}$ saturation, and improve conditions for plant growth generally [100-104]. Similarly, the addition of plant residue composts, urban waste compost, animal manure, and coal-derived organic products to acid soils increases soil $\mathrm{pH}$, decreases $\mathrm{Al}^{3+}$ saturation, and improves conditions for plant growth [8,13,105-107]. The recycling of these waste products for soil amelioration has a double benefit for both the environment and the economy, provided that the waste materials are not contaminated with harmful impurities. These organic substances confer metal binding and $\mathrm{pH}$ buffering capacities, which are important determinants of the $\mathrm{pH}$ of the treated soil $[104,108,109]$.

Treatment of sludge as a soil ameliorator contributed to the reduction of $\mathrm{Al}^{3+}$ content and resulted in increased plant growth [8]. This result suggests that the sludge is a chelating agent for $\mathrm{Al}^{3+}[104,109,110]$. Although dolomite and sludge contribute to ameliorating the acidified soil, there are some serious concerns for the land application of dolomite and sewage sludge due to the potential for the contamination of ground water and eutrophication $[73,88,89,110]$. By stimulating the mineralization of soil organic matter, dolomitic liming causes ground water pollution by increasing nitrate release from the soil $[8,89,90]$. We, therefore, recommend restricting the use of those soil ameliorators.

Meanwhile, $\mathrm{N}$-fixing plants have been used for enhancing soil fertility in revegetation projects elsewhere (e.g., $[6,13,16])$. Therefore, we recommend planting $\mathrm{N}$-fixing plants as an initial step for revegetating in this area. 


\subsection{Selection of Plant Species for Restoration}

This study corresponds to a diagnostic assessment which analyzed the damage status of the forest ecosystem as a preparatory step for realizing the ecological restoration of this area $[19,20]$. Furthermore, we carried out a vegetation survey to obtain the reference information in a conservation reserve with similar environmental conditions, which was designated as the forest genetic resource reserve from the Korea Forest Administration.

Studies for restoration have chosen the species for restoration on the basis of the following criteria: (1) species importance for restoring the ecosystem function, (2) species that are to be the main components of the final ecosystem, and (3) many plants that make up the final biodiversity of the ecosystem and should be able to recolonize by their own efforts $[7,8,13,35]$.

In this study, we first selected the species lost in this study area by comparing and analyzing the vegetation data obtained from the damaged and natural reference areas.

Next, we selected tolerant species which can withstand the polluted environment. Tolerant plants were selected as species flourishing specifically in the damaged area and species showing higher frequency in the damaged area than in the reference area. Tolerant plants were selected by classifying the four vegetation layers of canopy tree, understory tree, shrub, and herb composing the vegetation profile.

Finally, we selected the pioneer species frequently invading the bare ground to restore the heavily damaged zone. Synthesized, the plant species to be introduced for restoration were selected by combining the tolerant species with the polluted environment, the pioneer species frequently invading with the bare ground, and the species disappeared from the damaged area compared with the species composition of the reference area (Table 6) $[7,13,36]$.

\section{Conclusions}

The result of a diagnostic assessment for the damaged forests around the Seokpo zinc smelter showed that ecological restoration is required urgently, as vegetation damage and soil acidification are very severe within the first ridge and at a distance of about $5 \mathrm{~km}$ from the pollution source. Vegetation damage appeared variously, such as the level to which bare ground appears due to extreme damage and the landslides that follow, the degree to which some of the vegetation strata is lost, and the visible damage level. The degree of soil acidification tended to be proportional to vegetation damage. In relation to soil acidification, deficiencies in nutrients, such as $\mathrm{Ca}^{2+}$ and $\mathrm{Mg}^{2+}$, and an increase in toxic ion concentration, such as $\mathrm{Al}^{3+}$, were also identified. In particular, landslides continued around places where vegetation was severely destroyed, making ecological restoration urgent. The restoration plan was prepared by compiling the results of these diagnostic assessments and reference information collected from intact natural forests. The restoration plan was prepared in two directions: amelioration of acidified soil and vegetation restoration. In order to successfully complete this ecological restoration, the continuous monitoring and management of soil and air pollution need to be prepared, as well as the continuous monitoring of the establishment process of the vegetation that is to be introduced.

Author Contributions: Conceptualization, A.R.K., C.H.L. and C.S.L; methodology, A.R.K., C.H.L. and C.S.L; software, A.R.K. and C.H.L.; validation, B.S.L., J.S. and C.S.L.; formal analysis, A.R.K. and C.H.L.; investigation, A.R.K., B.S.L., J.S., C.H.L., W.S.L., Y.H.Y.. C.S.L.; resources, C.H.L. and C.S.L.; data curation, B.S.L and J.S.; writing —original draft preparation, A.R.K.; writing-review and editing, Y.H.Y. and C.S.L.; visualization, A.R.K., B.S.L.; supervision, C.S.L.; project administration, C.S.L.; funding acquisition, C.S.L. All authors have read and agreed to the published version of the manuscript.

Funding: This research received no external funding.

Conflicts of Interest: The authors declare no conflict of interest. 


\section{Appendix A}

Table A1. Chemical Properties of Organic Fertilizer Planned as a Soil Ameliorator.

\begin{tabular}{cc}
\hline Environmental Factors & Content \\
\hline Water content (\%) & 48.34 \\
\hline Organic matter (\%) & 33.76 \\
\hline Total Nitrogen (\%) & 1.24 \\
\hline Available Phosphorus (\%) & 1.04 \\
\hline Exchangeable Potassium (\%) & 0.26 \\
\hline C.E.C (cmol+/kg) & 35.0 \\
\hline Sodium $(\%)$ & 0.57 \\
\hline
\end{tabular}

\section{References}

1. Bull, K.; Fench, G. International activities to reduce pollution impacts at the regional scale. In IUFRO Research Series 1, Forest Dynamics in Heavily Polluted Regions; Innes, J.L., Oleksyn, J., Eds.; CABI Publishing: Wallingford, UK, 2000.

2. Grennfelt, P.; Engleryd, A.; Forsius, M.; Hov, Ø.; Rodhe, H.; Cowling, E. Acid rain and air pollution: 50 years of progress in environmental science and policy. Ambio 2020, 49, 849-864. [CrossRef] [PubMed]

3. NIER (National Institute of Environmental Research). National Air Pollutants Emission; National Institute of Environmental Research: Gimpo, Korea, 2018.

4. Lee, H.; Lim, B.S.; Kim, D.U.; Kim, A.R.; Seol, J.W.; Lim, C.H.; Kil, J.H.; Moon, J.S.; Lee, C.S. Decline and passive restoration of forest vegetation around the Yeocheon industrial complex of Southern Korea. Forests 2020, 11, 674. [CrossRef]

5. Luttermann, A.; Freedman, B. Risks to Forests in Heavily Polluted Regions. Forest Dynamics in Heavily Polluted Regions; Report No. 1; IUFRO Task Force on Environmental Change; IUFRO: Vienna, Austria, 2000; pp. 9-26.

6. Winterhalder, K. Landscape degradation by smelter emissions near Sudbury, Canada, and subsequent amelioration and restoration. In IUFRO Research Series 1. Forest Dynamics in Heavily Polluted Regions; Innes, J.L., Oleksyn, J., Eds.; CABI Publishing: Wallingford, UK, 2000; pp. 87-119.

7. Lee, C.S.; Lee, K.S.; Hwangbo, J.K.; You, Y.H.; Kim, J.H. Selection of tolerant plants and their arrangement to restore a forest ecosystem damaged by air pollution. Water Air Soil Pollut. 2004, 156, 251-273. [CrossRef]

8. Lee, C.S.; Moon, J.S.; Cho, Y.C. Effects of soil amelioration and tree planting on restoration of an air-pollution damaged forest in South Korea. Water Air Soil Pollut. 2006, 179, 239-254. [CrossRef]

9. United Nations Environment Programme (UNEP). Annual Report 2009: Seizing the Hreen Opportunity; United Nations Environment Programme: Nairobi, Kenya, 2009.

10. Sicard, P.; Augustaitis, A.; Belyazid, S.; Calfapietra, C.; De Marco, A.; Fenn, M.E.; Bytnerowicz, A.; Grulke, N.E.; He, S.; Matyssek, R.; et al. Global topics and novel approaches in the study of air pollution, climate change and forest ecosystems. Environ. Pollut. 2016, 213, 977-987. [CrossRef]

11. Manisalidis, I.; Stavropoulou, E.; Stavropoulos, A.; Bezirtzoglou, E. Environmental and health impacts of air pollution: A review. Front. Public Health 2020, 8, 14. [CrossRef]

12. Lee, C.S.; Cho, Y.C.; Shin, H.C.; Lee, S.M.; Lee, C.H.; Eom, A.H. An evaluation of the effects of rehabilitation practiced in the coal mining spoils in Korea 2. An evaluation based on physic-chemical properties of soil. J. Ecol. Field Biol. 2008, 31, 25-30. [CrossRef]

13. Lee, C.S.; Cho, Y.C. Selection of pollution-tolerant trees for restoration of degraded forests and evaluation of the experimental restoration practices at the Ulsan Industrial Complex, Korea. In Ecology, Planning, and Management of Urban Forests: International Perspectives; Springer: New York, NY, USA, 2008; pp. 369-392.

14. Lee, C.S. Regeneration of Pinus densiflora Community around the Yeocheon Industrial Complex Disturbed by Air Pollution. Korean J. Ecol. 1993, 16, 305-316.

15. Ministry of Environment. Selection and Breeding of Tolerant Species and Bio-Indicator to Air Pollution and Acid Rain; Ministry of Environment: Seoul, Korea, 1996; p. 353.

16. Gunn, J.M. Restoration and Recovery of an Industrial Region: Progress in Restoring the Smelter-Damaged Landscape Near Sudbury, Canada; Springer: Berlin/Heidelberg, Germany, 1995.

17. Aronson, J.; Floret, C.; Le floc'h, E.; Ovalle, C.; Pontainer, P. Restoration and rehabilitation of degraded ecosystems in arid and semi-arid lands. A review from the South. Restor. Ecol. 1993, 1, 8-17. [CrossRef]

18. Berger, J.J. Ecological restoration and non indigenous plant species: A review. Restor. Ecol. 1993, 1, 74-82. [CrossRef]

19. SERI (Society Ecological Restoration International Science \& Policy Working Group). The SER International Primer on Ecological Restoration; Society for Ecological Restoration International: Tucson, AZ, USA, 2004.

20. McDonald, T.; Gann, G.; Jonson, J.; Dixon, K. International Standards for the Practice of Ecological Restoration-Including Principles and Key Concepts; Society for Ecological Restoration: Washington, DC, USA, 2016. 
21. Bradshaw, A. Ecological principles and land reclamation practice. Landsc. Plan. 1984, 11, 35-48. [CrossRef]

22. Bradshaw, A.D. The reclamation of derelict land and the ecology of ecosystems. In Restoration Ecology: A Synthetic Approach to Ecological Research; Jordan, W.R., Gilpin, M.E., Aber, A.D., Eds.; Cambridge University Press: Cambridge, UK, 1987 ; pp. 53-74.

23. Cairns, J. Is restoration ecology practical? Restor. Ecol. 1993, 1, 3-7. [CrossRef]

24. Cairns, J.; Heckman, J.R. Restoration ecology: The state of an emerging field. Annu. Rev. Energy Environ. 1996, 21, 167-189. [CrossRef]

25. Hobbs, R.; Norton, D.A. Towards a conceptual framework for restoration ecology. Restor. Ecol. 1996, 4, 93-110. [CrossRef]

26. Jordan, W.R.; Ii, R.L.P.; Allen, E.B. Ecological restoration as a strategy for conserving biological diversity. Environ. Manag. 1988, 12, 55-72. [CrossRef]

27. Naveh, Z. From biodiversity to ecodiversity: A landscape-ecology approach to conservation and restoration. Restor. Ecol. 1994, 2, 180-189. [CrossRef]

28. Turner, F. The invented landscape. In Beyond Preservation: Restoring and Inventing Landscapes; Baldwin, A.D.J., De Luce, J., Pletsch, C., Eds.; University of Minnesota Press: Minneapolis, MN, USA, 1994; pp. 35-66.

29. Bradshaw, A.D. The biology of land restoration. In Applied Population Biology; Jain, S.K., Botsford, J.W., Eds.; Kluwer: Dordrecht, The Netherlands, 1992; pp. 25-44.

30. Temperton, V.M.; Zirr, K. Order of arrival and availability of safe sites: An example of their importance for plant community assembly in stressed ecosystems. In Assembly Rules and Restoration Ecology-Bridging the Gap between Theory and Practice; Temperton, V.M., Hobbs, R., Nuttle, T., Halle, S., Eds.; Island Press: Washington, DC, USA, 2004; pp. 285-303.

31. Hough, M. City Form and Natural Process; Croom Helm: London, UK, 1984; p. 279.

32. Aber, J.D. Restored forests and the identification of critical factors in species-site interactions. In Restoration Ecology: A Synthetic Approach to Ecological Research; Jordan, W.R., Gilpin, M.E., Aber, J.D., Eds.; Cambridge University Press: Cambridge, UK, 1987; pp. 241-250.

33. MacMahon, J.A. Disturbed lands and ecological theory: An essay about a mutualistic association. In Restoration Ecology; Jordan, W.R., Gilpin, M.E., Aber, J.D., Eds.; Cambridge University Press: Cambridge, UK, 1987; pp. 221-240.

34. Gunn, J.M. Restoring the smelter-damaged landscape near Sudbury, Canada. Ecol. Restor. 1996, 14, 129-136. [CrossRef]

35. Dobson, A.P.; Bradshaw, A.D.; Baker, A.J.M. Hopes for the future: Restoration ecology and conservation biology. Science 1997, 277, 515-522. [CrossRef]

36. Kim, G.S.; Pee, J.H.; An, J.H.; Lim, C.H.; Lee, C.S. Selection of air pollution tolerant plants through the 20-years-long transplanting experiment in the Yeocheon industrial area, southern Korea. Anim. Cells Syst. 2015, 19, 208-215. [CrossRef]

37. Kercher, J.; Axelrod, M.; Bingham, G. Forecasting effects of S02 pollution on growth and succession in a Western conifer forest. In Proceedings of the Symposium on Effects of Air Pollutants on Mediterranean and Temperate Forest Ecosystems, Riverside, CA, USA, 22-27 June 1980; p. 200.

38. Kozlowski, T.T. Impacts of air pollution on forest ecosystems. BioScience 1980, 30, 88-93. [CrossRef]

39. Healey, M.; Raine, A.; Parsons, L.; Cook, N. River Condition Index in New South Wales: Method Development and Application; NSW Office of Water: Sydney, Australia, 2012.

40. Munné, A.; Solà, C.; Rieradevall, M.; Prat, N. Índex QBR. Mètode per a l'avaluació de la qualitat dels ecosistemes de ribera. Estud. Qual. Ecol. 1998, 4, 28. (In Catalan)

41. Webb, B.W.; Petts, G.E.; Möller, H.; Roux, A.L. Historical change of large alluvial rivers: Western Europe. Geogr. J. 1990, $156,91$. [CrossRef]

42. Mant, J.; Janes, M. Restoration of rivers and floodplains. In Restoration Ecology; Blackwell Publishing: Malden, MA, USA, 2005; pp. 141-157.

43. Kuemmerlen, M.; Reichert, P.; Siber, R.; Schuwirth, N. Ecological assessment of river networks: From reach to catchment scale. Sci. Total Environ. 2019, 650, 1613-1627. [CrossRef] [PubMed]

44. Kim, A.R.; Kim, D.U.; Lim, B.S.; Seol, J.W.; Lee, C.S. An evaluation on restoration effect in the restored Yangjae stream and the improvement plan based on the result. Korean J. Ecol. Environ. 2020, 53, 390-407. [CrossRef]

45. Lee, C.S.; Cho, Y.C.; Shin, H.C.; Moon, J.S.; Lee, B.C.; Bae, Y.S.; Byun, H.G.; Yi, H. Ecological response of streams in Korea under different management regimes. Water Eng. Res. 2005, 6, 131-147.

46. An, J.H.; Lim, C.H.; Lim, Y.K.; Nam, K.B.; Lee, C.S. A review of restoration project evaluation and post management for ecological restoration of the river. J. Restor. Ecol. 2014, 4, 15-34.

47. Jung, S.H.; Kim, A.R.; Seol, J.W.; Lim, B.S.; Lee, C.S. Characteristics and reference information of riparian vegetation for realizing ecological restoration classified by reach of the river in Korea. J. Korean Soc. Water Environ. 2018, 34, 447-461.

48. Lee, C.S.; Jeong, Y.M.; Kang, H.S. Concept, direction, and task of ecological restoration. J. Restor. Ecol. $2011,2,59-71$.

49. Reif, D.M.; Martin, M.T.; Tan, S.W.; Houck, K.A.; Judson, R.S.; Richard, A.M.; Knudsen, T.B.; Dix, D.J.; Kavlock, R.J. Endocrine profiling and prioritization of environmental chemicals using ToxCast data. Env. Health Perspect. 2010, 118, $1714-1720$.

50. Lee, C.S. Role and task of restoration ecology in changing environment. Proc. Natl. Acad. Sci. USA 2015, 2015, 481-527.

51. Korea Forest Service. Study on the Cause of Forest Damage and Restoration Plan in Seokpo; Korea Forest Service: Daejeon, Korea, 2019; p. 357.

52. Jury, M.R. Meteorology of air pollution in Los Angeles. Atmos. Pollut. Res. 2020, 11, 1226-1237. [CrossRef]

53. Bonan, G. Ecological Climatology: Concepts and Applications, 1st ed.; Cambridge University Press: Cambridge, UK, $2002 ;$ p. 678. 
54. Korea Metrological Administration. Climatological Normals 1981-2010. Available online: https://www.weather.go.kr/weather/ climate/average_30years.jsp?yy_st=2011\&stn=271\&norm $=Y \& x=9 \& y=18 \& o b s=T A$ (accessed on 10 April 2021).

55. Korea Forest Service. Forest Soil Map. Available online: https://www.forest.go.kr/newkfsweb/html/HtmlPage.do?pg=/fgis/ UI_KFS_5002_020200.html\&mn=KFS_02_04_03_04_02\&orgId=fgis (accessed on 10 April 2021).

56. National Institute of Ecology. National Ecosystem Survey. Available online: https://www.nie-ecobank.kr/spceinfo/main.do (accessed on 14 February 2019).

57. Küchler, A.W.; Zonneveld, I.S. Vegetation Mapping; Kluwer Academic Publishers: Boston, MA, USA, 1988.

58. ESRI. Arcview GIS; Environmental System Research Institute: Redlands, CA, USA, 2005.

59. ESRI. Image Classification Using the ArcGIS Spatial Analyst Extension, 10.3; ESRI: Redlands, CA, USA, 2014.

60. Richards, J.A. Remote Sensing Digital Image Analysis; Springer: Berlin, Germany, 1999; Volume 3, pp. 10-38.

61. Haque, M.I.; Basak, R. Land cover change detection using GIS and remote sensing techniques: A spatio-temporal study on Tanguar Haor, Sunamganj, Bangladesh. Egypt. J. Remote Sens. Space Sci. 2017, 20, 251-263. [CrossRef]

62. Gordon, A.G.; Gorham, E. Ecological aspects of air pollution from an iron-sintering plant at Wawa, Ontario. Can. J. Bot. 1963, 41, 1063-1078. [CrossRef]

63. Ellenberg, D.; Mueller-Dombois, D. Aims and Methods of Vegetation Ecology; Wiley: New York, NY, USA, 1974.

64. Jackson, M.L. Soil Chemical Analysis; Prentice-Hall: New Delhi, India, 1967; p. 498.

65. Allen, S.E.; Grimshaw, H.M.; Rowland, A.P. Chemical analysis. In Methods in Plant Ecology; Moore, P.D., Chapman, S.B., Eds.; Blackwell: Oxford, UK, 1986.

66. SAS Institute. PROC User's Manual, 6th ed.; SAS Institute: Cary, NA, USA, 2001; p. 956.

67. Jeong, J.H.; Koo, K.S.; Lee, C.H.; Kim, C.S. Physic-chemical properties of Korean forest soils by regions. J. Korean Soc. 2002, 91, 694-700. (In Korean)

68. Rietkerk, M.; van den Bosch, F.; van de Koppel, J. Site-specific properties and irreversible vegetation changes in semi-arid grazing systems. Oikos 1997, 80, 241-252. [CrossRef]

69. National Institute of Ecology. Ecology and Nature Map. Available online: https:/ /www.nie-ecobank.kr/ (accessed on 10 April 2021).

70. Kim, H.Y.; Cho, H.J. Vegetation composition and structure of Sogwang-ri forest genetic resources reserve in Uljin-gun, Korea. Korean J. Environ. Ecol. 2017, 31, 188-201. [CrossRef]

71. Lorenz, M.; Clarke, N.; Paoletti, E.; Bytnerowicz, A.; Grulke, N.; Lukina, N.; Sase, H.; Staelens, J. Air Pollution Impacts on Forests in a Changing Climate; Forest and Society-Responding to Global Drivers of Change, IUFRO World Series; International Union of Forest Research Organizations: Vienna, Austria, 2010; Volume 25, pp. 55-74.

72. Smith, W.H. Air Pollution and Forests: Interactions between Air Contaminants and Forest Ecosystems; Springer Science \& Business Media: Berlin, Germany, 1990.

73. Freedman, B. Environmental Ecology: The Ecological Effects of Pollution, Disturbance, and Other Stresses, 2nd ed.; Academic Press: San Diego, CA, USA, 1995.

74. Longhurst, J.W.S.; Owen, P.S.; Conlan, D.E.; Watson, A.F.R.; Raper, D.W. Atmospheric pollution: Components, mechanisms, control and remediation. In Clean Technology and the Environment; Kirkwood, R.C., Longley, A.J., Eds.; Springer: Dordrecht, The Netherlands, 1995.

75. Zawar-Reza, P.; Spronken-Smith, R. Air pollution climatology. In Encyclopedia of World Climatology. Encyclopedia of Earth Sciences Series; Oliver, J.E., Ed.; Springer: Dordrecht, The Netherlands, 2005.

76. Akimoto, H.; Luangjame, J.; Hara, H.; Gromov, S.; Khummongkol, P.; Carandang, W. The second periodic report on the state of acid deposition in East Asia. In Part I. Regional Assessment; Acid Deposition Monitoring Network in East Asia: Bangkok, Thailand, 2011 ; p. 270.

77. Rau, H. Das Papsttum: Seine Entstehung, Seine Blüthe und Sein Verfall; G. Stöckhardt: Stuttgart, Germany, 1871. (In German)

78. Saliba, N.A.; Mochida, M.; Finlayson-Pitts, B.J. Laboratory studies of sources of HONO in polluted urban atmospheres. Geophys. Res. Lett. 2000, 27, 3229-3232. [CrossRef]

79. Ramadan, A.E.K. Acid deposition phenomena. TESCE 2004, 30, 1369-1389.

80. Wuana, R.A.; Okieimen, F.E. Heavy metals in contaminated soils: A review of sources, chemistry, risks and best available strategies for remediation. Int. Sch. Res. Netw. Isrn Ecol. 2011, 2011, 402647. [CrossRef]

81. Masindi, V.; Muedi, K.L. Environmental contamination by heavy metals. Heavy Met. 2018, 115-133. [CrossRef]

82. Hervás, J. Lessons Learnt from Landslide Disasters in Europe; European Communities: Luxembourg, 2003 ; p. 91.

83. Gupta, A.K.; Nair, S.S. Ecosystem Approach to Disaster Risk Reduction; National Institute of Disaster Management: New Delhi, India, 2012; p. 202.

84. Ryu, S.R.; Choi, H.T.; Lim, J.H.; Lee, I.K.; Ahn, Y.S. Post-fire restoration plan for sustainable forest management in South Korea. Forests 2017, 8, 188. [CrossRef]

85. Briffa, J.; Sinagra, E.; Blundell, R. Heavy metal pollution in the environment and their toxicological effects on humans. Heliyon 2020, 6, e04691. [CrossRef] [PubMed]

86. Lee, C.S.; Kim, J.Y.; You, Y.H. Amelioration of soil acidified by air pollutant around the industrial complexes. Korean J. Ecol. 1998, 21, 313-320.

87. Edmeades, D.C.; Ridley, A.M. Using lime to ameliorate topsoil and subsoil acidity. In Handbook of Soil Acidity; Rengel, Z., Ed.; Marcel Dekker: New York, NY, USA, 2003; pp. 297-336. 
88. Kaupenjohann, M.; Hantschel, R.; Zech, W.; Horn, R. Ergebnisse von Düngungsversuchen mit Magnesium and vermutlich immissionsgeschädigten Fichten [Picea abies (L.) Karst.] im Fichtelgebirge. Forstwiss Cent. 1987, 106, 78-84. (In German) [CrossRef]

89. Kreutzer, K. Effects of forest liming on soil processes. In Nutrient Uptake and Cycling in Forest Ecosystems; Springer: Dordrecht, The Netherlands, 1995; pp. 447-470.

90. Matzner, E.; Meiwes, K.J. Effects of liming and fertilization on soil solution chemistry in North German forest ecosystems. Water Air Soil Pollut. 1991, 54, 377-389.

91. Borgegard, S.S.; Rydin, H. Utilization of waste products and inorganic fertilizer in the restoration of iron mine tailings. J. Appl. Ecol. 1989, 26, 1083-1088. [CrossRef]

92. Blamey, E.P.C.; Edwards, D.G. Limitations to food crop production in tropical acid soils. In Nutrient Management for Food Crop Production in Tropical Farming Systems; van der Heide, J., Ed.; Institute for Soil Fertility: Haren, The Netherlands, 1989; pp. 73-94.

93. Yang, Z.B.; Rao, I.M.; Horst, W.J. Interaction of aluminum and drought stress on root growth and crop yield on acid soils. Plant Soil 2013, 372, 3-25. [CrossRef]

94. Awad, K.M.; Salih, A.M.; Khalaf, Y.; Suhim, A.A.; Abass, M.H. Phytotoxic and genotoxic effect of Aluminum to date palm (Phoenix dactylifera L.) in vitro cultures. J. Genet. Eng. Biotechnol. 2019, 17, 7. [CrossRef]

95. Kochain, L.V. Cellular mechanisms of aluminum toxicity and resistance in plants. Annu. Rev. Plant Physiol. Plant Mol. Biol. 1995, 46, 237-260. [CrossRef]

96. Rahman, M.A.; Lee, S.H.; Ji, H.C.; Kabir, A.H.; Jones, C.S.; Lee, K.W. Importance of mineral nutrition for mitigating aluminum toxicity in plants on acidic soils: Current status and opportunities. Int. J. Mol. Sci. 2018, 19, 3073. [CrossRef]

97. Sumner, M.E.; Fey, M.V.; Noble, A.D. Nutrient status and toxicity problems in acid soils. In Soil Acidity; Ulrich, B., Sumner, M.E., Eds.; Springer: Berlin, Germany, 1991; pp. 149-182.

98. Song, Z.; Wan, F.; Chang, X.; Zhang, J.; Sun, M.; Liu, Y. Effects of nutrient deficiency on root morphology and nutrient allocation in Pistacia chinensis bunge seedlings. Forests 2019, 10, 1035. [CrossRef]

99. Hoyt, P.B.; Turner, R.C. Effects of organic materials added to very acid soils on pH, aluminum, exchangeable NH4, and crop yields. Soil Sci. 1975, 119, 227-237. [CrossRef]

100. Asghar, M.; Kanehiro, Y. Effects of sugar-cane trash and pineapple residue on soil $\mathrm{pH}$, redox potential, extractable $\mathrm{Al}$, Fe and $\mathrm{Mn}$. Trop. Agric. 1980, 57, 245-258.

101. Ahmad, F.; Tan, K.H. Effect of lime and organic matter on soybean seedlings grown in aluminum-toxic soil. Soil Sci. Soc. Am. J. 1986, 50, 656-661. [CrossRef]

102. Bessho, T.; Bell, L.C. Soil solid and solution phase changes and mung bean response during amelioration of aluminium toxicity with organic matter. Plant Soil 1992, 140, 183-196. [CrossRef]

103. Wong, M.T.F.; Swift, R.S. Role of organic matter in alleviating soil acidity. In Handbook of Soil Acidity; Rengel, Z., Ed.; Marcel Dekker: New York, NY, USA, 2003; pp. 337-358.

104. Hue, N.V.; Amien, I. Aluminum detoxification with green manures. Commun. Soil Sci. Plant Anal. 1989, 20, 1499-1511. [CrossRef]

105. Alter, D.; Mitchell, A. Use of vermicompost extract as an aluminium inhibitor in aqueous solutions. Commun. Soil Sci. Plant Anal. 1992, 23, 231-240. [CrossRef]

106. Hue, N.V. Correcting soil acidity of a highly weathered Ultisol with chicken manure and sewage sludge. Commun. Soil Sci. Plant Anal. 1992, 23, 241-264. [CrossRef]

107. Rowley, M.C.; Grand, S.; Verrecchia, É.P. Calcium-mediated stabilisation of soil organic carbon. Biogeochemistry 2018, 137, 27-49. [CrossRef]

108. Wei, H.; Liu, Y.; Xiang, H.; Zhang, J.; Li, S.; Yang, J. Soil pH responses to simulated acid rain leaching in three agricultural soils. Sustainability 2020, 12, 280. [CrossRef]

109. de la Fuente, J.M.; Verenice, R.R.; Jose Luis, C.P.; Luis, H.E. Aluminum tolerance in transgenic plants by alteration of citrate synthesis. Science 1997, 276, 1566-1568. [CrossRef] [PubMed]

110. Singh, R.P.; Singh, P.; Ibrahim, M.H.; Hashim, R. Land application of sewage sludge: Physic-chemical and microbial response. Rev. Environ. Contam. Toxicol. 2011, 214, 41-61. [CrossRef] 